\title{
Deterring Delinquents: A Rational Choice Model of Theft and Violence
}

\author{
Ross L. Matsueda \\ University of Washington
}

\author{
Derek A. Kreager \\ University of Washington
}

\section{David Huizinga \\ University of Colorado}

This article examines criminal behavior from a rational choice perspective, the set of behavioral principles underlying our legal institution. The authors use a subjective utility approach and specify experiential learning models of the formation of risk perceptions and rational choice models of theft and violence. They estimate the models using panel data on high risk youth from the Denver Youth Survey. Using random effects Tobit models of perceived risk and negative binomial models of counts of criminal acts, the authors find support for a rational choice model. Perceived risk follows a Bayesian updating model in which current risk perceptions are a function of prior risk perceptions plus new information based on experience with crime and arrest and observations of peers. Theft and violence are a function of the perceived risk of arrest, subjective psychic rewards (including excitement and social status), and perceived opportunities.

\section{Delivered by Ingenta to :}

University of Wisconsin-Madison (cid 80004773), Ebling Lib Info Res Unit (cid 292294), matsueda

$\mathrm{R}$ ational choice theories have advanced considerably in the social sciences, particularly in economics, political science, and law (e.g., Morrow 1994; Posner 1998; Sunstein 1999). In sociology, especially with the popularity of social capital theory, rational choice has gained traction as an individual-level theory of motivation compatible with macro-level theories of

Direct correspondence to Ross L. Matsueda, Department of Sociology, Box 353340, University of Washington, Seattle, WA 98195 (matsueda@, u.washington.edu). Supported by grants from the National Science Foundation (SES-0004323), the Royalty Research Fund of the University of Washington, and the Office of Juvenile Justice and Delinquency Prevention (1996-MU-FX-0017). The funding agencies bear no responsibility for the analyses and interpretations drawn here. This article is a revised version of a paper presented at the annual meetings of the American Sociological Association, Atlanta, August 16-19, 2003. The authors thank Irving Piliavin for helping to design the rational choice instrument used here; and Kate Stovel, Greg Pogarsky, three anonymous reviewers, and the $A S R$ editor for comments on an earlier draft. social structure (Coleman 1990). Nevertheless, skepticism in sociology persists, in part due to misconceptions, but more importantly due to questions about the explanatory power of rational choice theories. Proponents and skeptics alike agree that a fair assessment of the theory asks whether it has paid off empirically. Hechter and Kanazawa (1997) conclude that some empirical studies support rational explanations (sometimes unwittingly) in areas beyond market behavior, but that additional research is needed to examine rational choice theory in a variety of areas of social life and forms of social action.

A challenging and important empirical puzzle for rational choice theory concerns the social control of criminal behavior. Crime is a difficult case for rational choice theory. In the case of street crime, behavior is typically characterized as irrational and suboptimal. This is in contrast to market behavior, financial decisions, and corporate crime, where institutionalized norms frame decision making in the terms of rationality or optimality. Indeed, the media - and some academics — commonly portray street criminals as impulsive, unthinking, 
and uneducated, and their behaviors as beyond the reach of formal sanctions (e.g., Gottfredson and Hirschi 1990). Thus, a finding that street crimes follow rational choice principles would provide strong evidence for rational choice perspectives.

Crime is an important arena for investigating rational choice for another reason: Utilitarian principles, and their accompanying psychological assumptions, undergird our legal institution (e.g., Maestro 1973). This connection is rooted in writings of the classical school. Long ago, Bentham ([1789] 1948) argued that happiness is a composite of maximum pleasure and minimum pain, and that the utilitarian principlethe greatest happiness for the greatest number - underlies morals and legislation. For Bentham, punishment by the state constitutes one of four sanctions - political, moral, physical, and religious - that shape pleasures and pains. Beccaria ([1764] 1963), influenced by the moral philosophers of the Enlightenment, assumed that criminal laws reflect the terms of a social contract, in which members of society receive protection of their rights to personal welfare and private property in exchange for relinquishing the freedom to violate the rights of others. Those rights are protected by the state through deterrence, threatening potential transgressors with just enough punishment to outweigh the pleasures of crime. ${ }^{1}$ Beccaria attempted to reform the unjust and brutal legal system of eighteenth-century Europe by developing a rational system that specified laws clearly and a priori (so individuals have full information about the consequences of their acts), eliminated judicial discretion (so all citizens are equal in the eyes of the law), and made punishments certain, swift, and no more severe then needed to deter the public from crime.

Critical legal scholars, however, challenge this view of the legal system. They see the system as an ideological justification (manifest function) of modern capitalist societies, which disguises its true essence (latent function) as legitimizing inequitable class relations. For

${ }^{1}$ The form of U.S. criminal laws reflects utility and deterrence theories: rather than moralizing about illegal acts, the statutes stipulate, simply and dispassionately, that whosoever engages in a certain crime will be punished with a certain sanction. example, Pashukanis ([1929] 1978:169) develops a Marxist commodity exchange theory of law, whereby under capitalism, punishment becomes an exchange "in which the offender 'pays his debt' and wherein crime becomes 'an involuntarily concluded contract'" (Garland 1990:113). For Garland (1990:117), "the key to understanding criminal law in class terms is to appreciate the ways in which particular interests are interwoven with general ones," such that protection of class interests are disguised as protection of universal interests. As for deterrence, he argues that "the simple fact is that no method of punishment has ever achieved high rates of reform or of crime control-and no method ever will" (Garland 1990:228). Our purpose is not to adjudicate between views of the legal system as a mechanism for achieving the greatest happiness for the greatest number, as Bentham ([1789] 1948) and Beccaria ([1764] $1963)$ argue, or as a tool for exercising "class terror" and mystifying class relations, as Pashukanis and Garland argue. Rather, our objective is to examine the question of rational choice and deterrence, which cuts to the core of assumptions underlying our legal institution. Do individuals act as if they are rational and respond to incentives, as rational choice and classical theorists assume? Or does conformity lie principally outside the purview of punishment and rational choice as Garland and other sociologists of law maintain?

Recent treatments of rational choice and deterrence follow Becker's (1968) seminal article outlining an expected utility model of criminal decision making (see McCarthy 2002). Becker's model specifies that individuals will engage in crime when expected utility from committing crime is greater than expected utility from not committing crime. The utility function, in turn, is a function of two additive components: (1) the utility of returns from crime (the "booty") weighted by the objective probability of getting away with it; plus (2) the utility of returns minus the punishment, each weighted by the objective probability of getting caught and punished.

Early empirical studies of Becker's model use statistical models of aggregate crime rates and focus on deterrent effects of risk of imprisonment (measured by imprisonment per capita) or risk of arrest (measured by arrests per reported crimes). Ehrlich (1973) found deterrent 
effects of imprisonment but scholars criticized him for using simultaneous equation models with implausible solutions to the identification problem - such as assuming socioeconomic status (SES), region, and population age have no effect on crime (Nagin 1978). More recent work has unearthed deterrent effects using more plausible instrumental variables. For example, Sampson and Cohen (1988), following the work of Wilson and Boland (1978), use aggressive policing as an instrument for risk of arrest (arrest per reported crime). Also, Levitt (1997) uses the timing of mayoral elections as an instrument for number of police per capita (see also Marvell and Moody 1994). For a review of this work, see Nagin (1998).

These tests of the deterrence hypothesis assume that actors know the objective certainty of arrest and imprisonment. This is perhaps the most questionable assumption of expected utility models. Subjective expected utility models, in contrast, relax this assumption, replacing the single known objective probability with a distribution of subjective probabilities. Subjective utility models, however, direestill rational models because the statistical mean of the subjective probability distribution is assumed to fall on the value of the objective probability (Nagin 1998). Moreover, by specifying that subjective costs and returns are the key determinants of criminal decision making, subjective expected utility models open new puzzles and new ways of testing rational choice. In particular, we can use direct measures of subjective expected costs and returns and examine whether they conform to rational models of their causes and consequences.

A crucial subjective cost of crime is the perceived risk of formal sanction. The important policy and theoretical question is that of deterrence: Do individuals with higher perceptions of the risk of punishment commit fewer criminal acts? Here, prior research is equivocal: Longitudinal panel studies of perceived risk and self reported delinquency find weak or nonsignificant deterrent effects (Paternoster 1987), whereas vignette studies of perceived risk and intentions to commit crime find significant deterrent effects (Nagin 1998). We reassess these results in this article using new data on high risk youth.

But returns to crime may be just as important as costs. Here, a thorny issue involves specify- ing the relevant perceived rewards of crime for individuals located within specific structural and cultural contexts. Obviously, pecuniary returns are important for monetary crimes. But ethnographic research suggests that psychic returns, such as excitement, thrills, and status within peer groups, may be even more important. Identifying the psychic rewards from ordinary street crimes is essential to testing a rational choice theory of crime. Moreover, some research suggests that perceived rewards dominate costs in criminal decision making - presumably because criminals discount formal punishment due to its long time horizon (e.g., Carroll 1978; Piliavin et al. 1986). We revisit and reevaluate this finding here.

From both a theoretical and policy standpoint, a question as important as predicting criminal behavior concerns the formation of risk perceptions: Are risk perceptions related to actual experiences of punishment (Nagin 1998)? Rational choice theory assumes that risk perceptions are rooted, at least to some degree, in reality. Deterrence theory and policy also make this assumption - if actual punishments fail to increase perceptions of risks, pounitive policies will fail (Jacob 1979). Thus, modeling the formation of risk perceptions, which requires an information theory of risk formation, gives us another way of testing both rational choice and deterrence theories.

\section{FORMATION OF RISK PERCEPTIONS: AN EXPERIENTIAL LEARNING MODEL}

\section{BAYESIAN LEARNING}

An important question in the sociology of risk and decision making concerns how individuals form their perceptions of risk (Tallman and Gray 1990; Heimer 1988). This literature contrasts a Bayesian learning process with alternative models based on heuristics and biases (Kahneman and Tversky 1972). According to a Bayesian learning model-based on Bayes' probability theorem - individuals begin with a prior subjective probability of an event, such as the risk of arrest, based on all the information they have accumulated to that point. They then collect or come into contact with new information - such as learning of a friend's arrest or being arrested themselves - which they use to update their probability estimates. This new probability, or "posterior probability," is a com- 
bination of the prior probability and the new information. Applied to the formation of perceived risk, we would expect that updated risks are a function of prior risk plus new information. Bayesian learning has been examined by economists to model consumers' evaluations of new products (McFadden and Train 1996), by political scientists to model voting and party affiliation (Achen 1992), and by psychologists to model court testimony scenarios (Winterfeldt and Edwards 1986). Moreover, Nagin (1998) suggested that this model can be applied to the formation of perceptions of the risk of arrest. Such a process is consistent with general social learning theories of crime (e.g., Akers 1998).

Cognitive psychologists, such as Tversky and Kahneman (1974), have criticized this view of learning. They use experimental evidence to find that actors depart from Bayesian learning by using cognitive shortcuts or heuristic rules, which can lead to biased and distorted risk perceptions (Tallman and Gray 1990). For example, individuals tend to update using only information that is easily or quickly retrieved from memory, so that dramatic and vivid events (sueh as arrest) may swamp other mundane sources of information (such as experiences of others). Individuals also tend to anchor their estimates on initial probabilities, rather than updating properly in light of new information, as when a person ignores the arrest of companions in forming risk perceptions. Furthermore, individuals tend to rely on stereotypes while ignoring population distributions, such as when a person overestimates the probability that a mother is black when given the information that she is a teenage mother (forgetting that whites are disproportionately represented in the population) (Heimer 1988).

In the case of certainty of sanction, individuals often rely on stereotypes depicted in the media, in which criminals are caught and arrested (Andenaes 1975; Parker and Grasmick 1979). Indeed, the media often manipulate this stereotype-e.g., with television shows like Cops (2005) - which may increase deterrent effects, particularly among naïve individuals with no experience with the criminal justice system. Research suggests that such naïve individuals tend to overestimate the likelihood that they will be arrested if they commit crimes (e.g., Jensen 1969), a phenomenon Tittle (1980:67) terms "the shell of illusion."
Finally, individuals fall prey to the gambler's fallacy, which occurs when a person assumes that a departure from what happens in the long run will be corrected in the short run. For example, if nine coin flips in a row have come up tails, individuals might think they are "due" for a coin flip to come up heads. Consequently, individuals who continuously get away with crime may think they are "due" for an arrest, or those who experience a string of arrests may think they are "due" to get away with crime (Pogarsky and Piquero 2003).

For our purposes, such heuristics suggest that the formation of perceived risks may not follow a strictly Bayesian learning perspective. Individuals may begin by overestimating their risk of arrest, remain anchored on their baseline values and fail to update, or update only on vivid events such as dramatic personal experiences.

\section{Formation of PERCEIVED RISK OF FORMAL SANCTION}

ItThe perceived risk of punishment for committing a crime rakes a god case study for Bayesian updating, because it is a clearly delineated risk and applies to all members of society. We specify three important sources of information from which individuals update their perceptions of risk of arrest: (1) their own experiences with offending, including getting arrested and avoiding arrest; (2) their knowledge of friends' experiences with offending; and (3) their social structural location. Drawing on a Bayesian learning perspective, we develop hypotheses about each of these sources of information.

An updating model (see Figure 1, bold lines) begins with a prior or baseline estimate of perceived risk of punishment:

\section{Hypothesis 1: Prior Perceived Risk: Future per- ceived risk is a positive function of prior perceived risk plus any updating.}

The key source of information for perceived risk is an individual's own experiences with crime and punishment. We use two concepts to capture these experiences. The first, "experienced certainty," refers to an individual's rate of arrests per number of reported crimes. We use this rate-rather than the absolute number of arrests - because the marginal effect of getting 


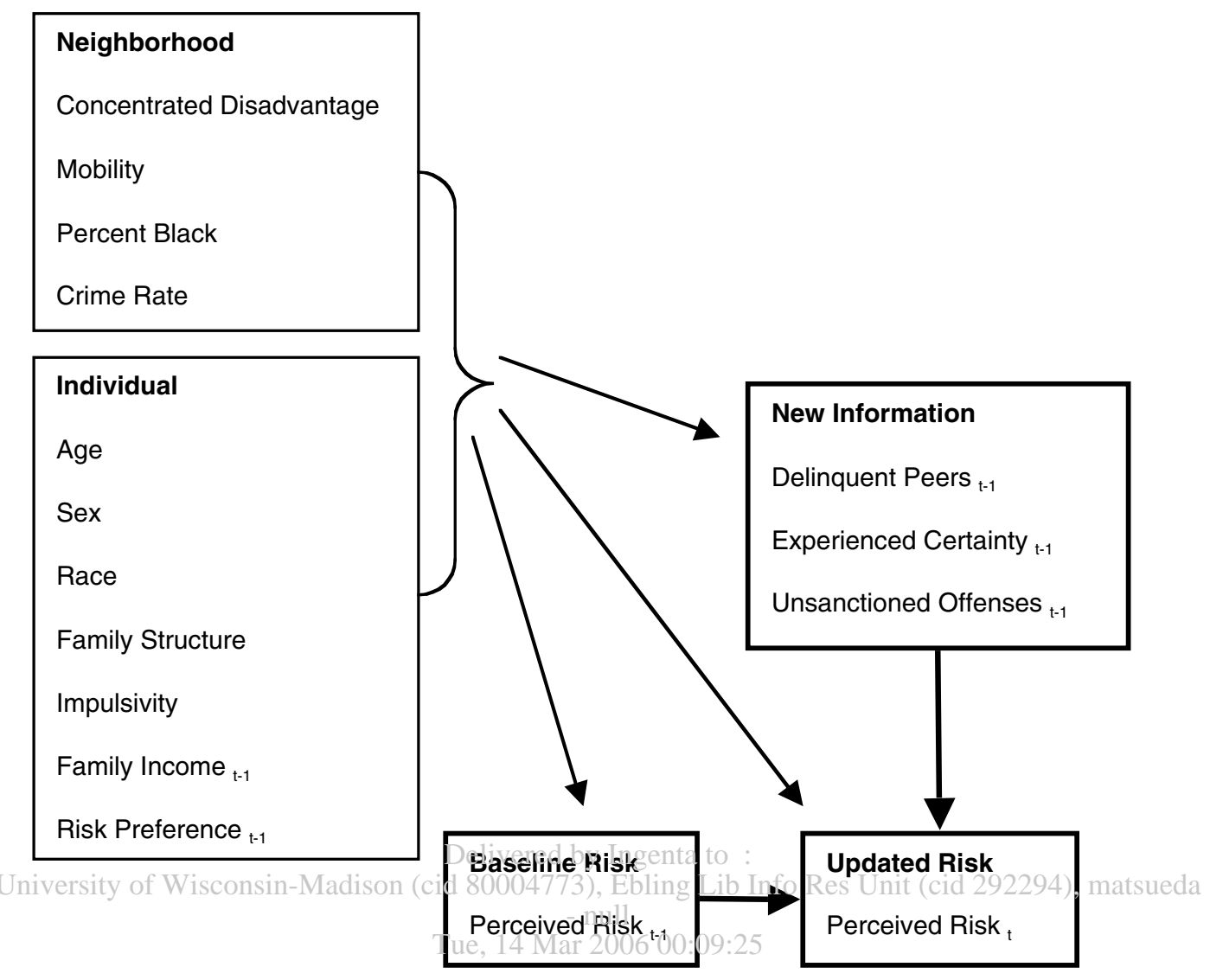

Figure 1. Experiential Learning Models of Perceived Risk of Arrest for Violence and Theft

Note: Bold lines and boxes refer to the basic updating model; other boxes and lines refer to controls.

arrested on perceived certainty of arrest diminishes with each undetected crime (Horney and Marshall 1992). This leads to our second hypothesis:

Hypothesis 2: Bayesian Learning Based on Personal Experience with Arrest: Net of prior risk, experienced certainty of arrest is positively and monotonically associated with perceived risk of arrest. ${ }^{2}$

${ }^{2}$ Our measures lack the precision to specify a functional form for this relationship. Thus, we simply examine the empirical distribution for monotonicity, where the relationship may be nonlinear but is always either increasing (positive) or decreasing (negative), but never both.
The second concept, "unsanctioned offenses," refers to the number of offenses committed by individuals who have never been arrested. For these individuals, experienced certainty scores will be zero, regardless of how many crimes they have committed. But clearly, from an updating standpoint, each time they commit a crime - and get away with it - they will update (lower) their perceptions of risk:

Hypothesis 3: Bayesian Learning Based on Personal Experience with Crime: Unsanctioned offenses (crimes by neverarrested persons) are negatively and monotonically associated with perceived risk of arrest.

Some studies offer qualified support for the Bayesian learning hypothesis. Parker and Grasmick (1979) find that among respondents 
who knew of at least one burglary, experienced certainty is positively correlated with certainty. They also find that those with zero experienced certainty have higher certainty estimates, and among those with no arrests, burglary is slightly negatively correlated with perceived certainty. In perhaps the strongest study of updating, Horney and Marshall (1992) interview incarcerated felons, compute experienced certainty (arrests per offense) for a variety of offenses, and find significant effects on perceived certainty of arrest for the offense. Finally, Pogarsky, Piquero, and Paternoster (2004) find that arrest increases future perceived certainty among high school students, particularly for those with low prior estimates of certainty. With respect to "unsanctioned offenses," research on the "experiential effect" finds strong effects of prior delinquency on risk of arrest (e.g., Paternoster 1987). Such research, however, fails to distinguish arrested from non-arrested groups, and thus, unsanctioned offenses from experienced certainty. Our analyses make this distinction and test the hypothesis directly. ${ }^{3}$

We can also test the hypothesis of a "shell of illusion," in which naïve iridividuals with no experience with offending or arrest overestimate the likelihood that they will be arrested if they commit crimes:

Hypothesis 4: Shell of Illusion: Compared to experienced offenders (with non-zero experienced certainty or unsanctioned offenses), naïve individuals overestimate the risk of arrest.

The second source of information is from peers. Over two decades ago, Cook (1980) theorized that risk perceptions are based on personal experiences with crime and punishment and the experiences of a few friends. Stafford and Warr (1993) make the same point, using the terms "punishment" and "punishment avoidance" to refer to a person's own punishment experience, and "vicarious punishment" and "vicarious punishment avoidance" to refer to peer experiences (see also Piquero and Pogarsky 2002). Ideally, the hypothesis would be that

${ }^{3}$ Lochner's (2005) unpublished study finds support for a learning model of perceived risk using data from the National Longitudinal Survey of Youth 1997 (NLSY-97) and National Youth Survey (NYS). perceived risk of arrest will increase with greater experienced certainty of peers, and decrease with greater peer unsanctioned offenses. Research on peer effects, however, has not directly examined experienced certainty of peers, but instead has examined the effect of delinquent peers on risk perceptions - and found significant effects. This strategy is probably a reasonable approximation, given that most offenses - particularly moderately serious offenses - go unsanctioned, and therefore, risk perceptions will decline with greater delinquency among peers (e.g., Parker and Grasmick 1979; Piquero and Pogarsky 2002; Pogarsky et al. 2004). Lacking data on experienced certainty of peers, we follow this strategy:

Hypothesis 5: Bayesian Learning Based on Vicarious Experience: Delinquent peers are negatively associated with perceived risk of arrest.

Finally, risk perceptions will be related to a person's location in the social structure (Douglas 1986). Social structural location will affect risk perceptions directly by structuring other sources of information and indirectly by a ffecting al: person's own experiences as well as structuring peer networks:

Hypothesis 6: Social Structure and Perceived

Risk: Perceived risk is shaped by location in the social structure (e.g., race, gender, SES, family structure, residential stability).

These hypotheses will allow us to determine whether or not individuals act like Bayesians in forming risk perceptions. But, of course, even if risk formation follows updating principles, a rational choice perspective will not be supported strongly unless perceived risks are related to behavior. We now turn to this central proposition of rational choice.

\section{RATIONAL CHOICE, DETERRENCE, AND DELINQUENCY}

Reduced to essentials, a rational choice model of deterrence and crime specifies that an individual will commit crime if the utility of rewards from crime (weighted by the probability of obtaining the reward) outweighs the utility of costs (weighted by the probability of being caught):

$$
\mathrm{P}_{\mathrm{R}} \mathrm{U}(\text { Rewards })>\mathrm{P}_{\mathrm{C}} \mathrm{U}(\text { Costs })
$$


where $P_{R}$ is the probability of receiving a reward, $P_{C}$ is the probability of a cost, and $U$ is a utility function that translates specific rewards and costs to a common metric (e.g., Becker 1968; Nagin and Pogarsky 2001). We treat the utilities as subjectively perceived by the actor.

Long ago, building on Beccaria's ([1764] 1963 ) ideas about crime and punishment, Jeremy Bentham ([1789] 1948) formalized and popularized David Hume's ([1739] 2000) concept of utility to refer to a calculation of pleasures and pains, which "point out what we ought to do, as well as determine what we shall do." Bentham hoped to categorize all pleasures and pains (e.g., pleasures of wealth, skill, power, expectation, and pains of enmity, malevolence, ill name, and the senses) and measure their value, using attributes of intensity, duration, certainty, propinquity, fecundity, purity, and extent. Kahneman, Wakker, and Sarin (1997) term Bentham's concept, "experienced utility," to contrast it to "decision utility," favored by economists and decision theorists. The latter eschews direct measurement of utility, arguing that utility cannot be observed, let alene measured. It opts instead to infer utility from the characteristics of behavioral choices, and then use that inferred utility to predict future behave ior. We follow Kahneman et al. (1997), and the tradition of Bentham, and measure utility directly using survey data. We use a straightforward measure of how good or bad the cost or reward would be to the individual to indicate perceived utility, and weight it by the probability of the cost or reward. The trick is to specify, from the standpoint of the actor, the relevant costs and returns of crime that affect criminal behavior.

\section{PeRCEIVED COSTS OF CRIME}

The perceived costs of crime are well established and include formal sanctions, such as arrest, conviction, jail, or imprisonment. For moderately serious crimes, research has focused on the perceived certainty of arrest, perhaps the most salient cost. Most cross-sectional vignette (scenario) studies of perceived risk and self-reported future intention to commit crime find consistent deterrent effects (e.g., Klepper and Nagin 1989; Nagin and Paternoster 1994). ${ }^{4}$

\footnotetext{
${ }^{4}$ In vignette studies, respondents are given scenarios of crime situations - where characteristics of
}

In contrast, most research using panel studies of self-reported crime find modest or null effects of perceived certainty on crime among college students (see reviews by Williams and Hawkins 1986; and Paternoster 1987) and serious offenders (e.g., Piliavin et al. 1986). ${ }^{5}$ We will use more refined measures of both perceived risk and of self-reported delinquency and reassess this latter finding:

\section{Hypothesis 7: Deterrence: Crime is reduced by perceptions of greater risk of formal sanc- tion weighted by perceived utility of the sanction.}

In addition to the cost of arrest, there are opportunity costs to offending - that is, opportunities forgone by virtue of crime. For adolescents and young adults, structural opportunity costs include schooling and work (e.g., Sullivan 1989; Sampson and Laub 1993). Youth who are performing well in school and who see schooling as an avenue to future status and pecuniary returns will be less likely to risk committing crime. Similarly, youth who seek employment will be less likely to jeopardize their legitimate earnings by committing crime With his social control theory of crime, Hirschi (1969) essentially:specified opportunity costs as the mechanism by which commitment to conventional lines of action reduced delinquency and found that school performance-but not employment-reduced delinquency. Subsequent research consistently finds negative effects of school performance on delinquency (e.g., Jenkins 1995; Stewart 2003). Research finds, however, that work exerts a positive effect on delinquency during adolescence, and this effect is stronger for individuals working more than 20 hours a week (e.g., Steinberg, Fegley, and Dornbusch 1993; Ploeger 1997; Wright, Cullen and Williams 1997). These effects persist when controlling for covariates that might select youth into jobs (Staff and Uggen 2003), but not in a fixed-effects panel model (Paternoster et al. 2003). This leads to the following hypothesis:

the scenario are randomly assigned — and asked to rate the risk of arrest (independent variable) as well as their hypothetical intention to commit the depicted crime (dependent variable).

${ }^{5}$ Lochner (2005) also finds support for the deterrence hypothesis using cross-sectional data from the NYS and longitudinal data from the NLSY-97. 
Hypothesis 8: Opportunity Costs: Crime is reduced by opportunity costs, including schooling and work.

\section{PERCEIVED RETURNS TO CRIME}

Returns to crime usually refer to income, which applies only to monetary crimes, and which is typically assumed to be confiscated upon formal sanction (and, therefore, modeled by replacing $\mathrm{P}_{\mathrm{R}}$ with $1-\mathrm{P}_{\mathrm{C}}$ ). For most crimes, however, criminological research has identified psychic returns as key determinants of criminal decisions. A long history of ethnographic research in criminology has identified peer group status as important in criminal decision making. For example, classical subcultural theories argue that for inner-city youth blocked from attaining conventional status, crime provides an alternative avenue for status in the eyes of a person's peers (e.g., Cloward and Ohlin 1960; Short and Strodtbeck 1965). More recent ethnographic research (e.g., Horowitz 1983; Anderson 1999) on inner-city Chicano and black youth finds that violence and crime often is a way ef attaining respect and honor among a person's reference group: "You do it 'cause you want to be cool" (Pinderhughes 1997:134). Katz (1988) argues that "being cool" is an important element of adolescent subcultures and a part of being "a badass," which is associated with street crime and violence. In his autobiographical account of a potentially violent confrontation in which he "couldn't resist the temptation to demand respect," Nathan McCall's (1994:378) thought process captures the role of rewards and status within a rational choice framework:

In a fraction of a second I calculated the possibilities and weighted the potential for loss and gain: He must be armed. Fistfighting went out with Afro picks and platform shoes. Even if by chance homeboy is an old-school rumbling man, I'll win no trophies or awards for throwing down with him. I told myself, Nathan, let it ride. Walk away from this one while you can.

Recent ethnographic accounts of property crimes find that excitement and thrills are ubiquitous and second only to monetary returns as important motivators (e.g., Tunnell 1992; Frazier and Meisenhelder 1985). Jacobs (2000:29) finds that robbers of drug dealers talk about the kicks and highs from robbery:
"It's like an adrenaline rush," Loony Ass Nigga proclaimed. "Some people go bungee jumping, some people go sky diving, I . . kick [drug] houses in." (p. 36)

Katz (1988) argues that criminals are often seduced into crime by the prospect of excitement and kicks or, what he terms, "sneaky thrills." Sneak thieves are often obsessed with "getting over" and the "excitement and thrill" from succeeding. If caught and arrested, they express shock, subsequently treat their theft as "real crime," and typically end their deviant career to avoid commitment to a deviant identity. In contrast, professional shoplifters see themselves as members of criminal subcultures and view their arrest as a "cost of doing business" (Katz 1988:66). Our models will draw on this literature to specify psychic returns to crime, such as getting excitement and thrills (see McCarthy and Hagan 2005), being seen as cool, and feeling good about oneself, and hypothesize that they affect crime:

Hypothesis 9: Psychic Returns to Crime: Criminal behavior is associated with perEblin ceived probability of excitement and social null status from crime weighted by perceived utility of the excitement or status.

\section{CRIMINAL OPPORTUNITIES}

Even if a person has determined that the rewards to crime outweigh the costs, that person cannot commit a crime until an objective opportunity is not only present but also perceived. With their routine activities theory, Cohen and Felson (1979) specify that criminal events occur at the intersection of motivated offenders, suitable targets, and the absence of capable guardians. Embedded in this theory is a rational, motivated actor seeking targets of theft or violence while avoiding detection. Indeed, Clarke and Cornish (1985) specify a rational choice theory of burglary in which perceived costs and benefits lead to a state of readiness to commit burglary, which interacts with an opportunity model of seeking suitable targets lacking capable guardians (to use the language of routine activities). Thus, from a rational standpoint, the important concept is the actor's perception of opportunities to get away with crime, which affects future crimes: 
Hypothesis 10: Criminal Opportunities: Criminal behavior is increased by perceptions of opportunities to get away with crime.

Research from a limited rationality perspective suggests that criminal behavior is associated with criminal opportunities and rewards, but not costs. Perhaps criminals have short time horizons, act on the basis of immediate opportunities, and tend to discount long-term consequences such as formal sanction (e.g., Wilson and Herrnstein 1985):

\section{Hypothesis 11: Limited Rationality and} Discounting: Criminal behavior is associated with perceptions of immediate criminal opportunities and rewards, but not by perceptions of future punishment.

Finally, deterrence theorists have traditionally argued that instrumental crimes, such as theft, burglary, and robbery, are more susceptible to rationality and deterrence than expressive crimes, such as violence, vandalism, and disorderly conduct (e.g., Chambliss 1967; Zimring and Hawkins 1973). McCarthy (2002) argues that this distinction is blurred in reality and that violence is often used instrumentally to gain status (e.g., Short and Strodbeck 1965; Anderson. 1999), while theft can be expressive (e.g., Cohen 1955). We treat this as an empirical question and distinguish between theft and violent acts:

Hypothesis 12: Instrumental versus Expressive Crimes: Rational choice and deterrence have stronger effects on theft than violence.

\section{DATA AND MEASURES}

\section{THE DENVER Youth SURVEY}

To test our models, we use data collected by Huizinga and colleagues as part of the Denver Youth Survey (DYS), a longitudinal study of delinquency and drug use in high risk neighborhoods in Denver. To identify high risk neighborhoods, they cluster analyzed census block groups based on census variables (e.g., family structure, ethnicity, SES, housing, mobility, marital status, and age composition), identified eleven clusters, and selected the three most socially disorganized clusters. They then selected those block groups within each cluster that fell within the top one-third of arrest rates based on reports of the Denver Police Department.
The resulting sample is representative of neighborhoods at high risk of delinquency, where high risk is defined as residing in socially disorganized, high-crime neighborhoods.

Using vacancy and completion rates, the investigators selected 20,300 of 48,000 enumerated households, drew a stratified probability sample of households proportional to population size, and then used a screening questionnaire to identify appropriately aged respondents (i.e., 7, 9, 11, 13 or 15 years old). This procedure yielded a sample of 1,528 completed interviews in the first wave, constituting a completion rate of $85 \%$ of eligible youths (see Esbensen and Huizinga 1990 for more details). Attrition rates were relatively low (7-9 percent) across the first five waves of data used here. Respondents age 11 years and older (at each wave) received a youth questionnaire with our rational choice measures. We use data from 11, $13-$, and 15-year-old cohorts between waves 2-5, 9-year-olds between waves 3-5, and 7year-olds between waves $4-5$. The total sample includes 1,459 respondents and 3,298 personyears, affer accounting for missing values on the

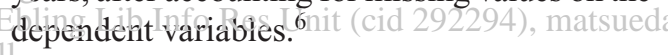

This sampling strategy has three implications for our analyses. First, we have adequate variation on our key rational choice and crime variables necessary for powerful tests of our rational choice hypotheses. Second, we can draw inferences to the important population of youth residing in high risk neighborhoods, but we must be careful to avoid generalizing to lowrisk neighborhoods. Third, we expect neighborhood characteristics related to social disorganization to have less variability in our sample and less explanatory power in our models.

\section{CONCEPTS AND MEASURES}

Descriptive statistics appear in Table 1; descriptions of our measures and concepts appear in the Appendix (Table A1). We include contextual and background variables describing the structural location of individuals. To measure neigh-

\footnotetext{
${ }^{6}$ We had slight (less than ten percent) missing values on some variables; we use a conditional mean imputation, which does not change the results appreciably.
} 
Table 1. Variable Descriptive Statistics

\begin{tabular}{|c|c|c|c|c|}
\hline & Minimum & Maximum & Mean or Proportion & $\mathrm{SD}$ \\
\hline \multicolumn{5}{|l|}{ Variables } \\
\hline Female & 0.00 & 1.00 & 0.47 & 0.50 \\
\hline Age & 11.00 & 20.00 & 15.08 & 2.41 \\
\hline Black & 0.00 & 1.00 & 0.33 & 0.47 \\
\hline Hispanic & 0.00 & 1.00 & 0.45 & 0.50 \\
\hline No Siblings & 0.00 & 1.00 & 0.53 & 0.50 \\
\hline Concentrated Disadvantage & -1.67 & 2.11 & 0.003 & 0.87 \\
\hline Proportion Black & 0.01 & 0.99 & 0.33 & 0.33 \\
\hline Residential Stability & -1.95 & 2.69 & 0.03 & 0.85 \\
\hline Crime Rate $1984^{\mathrm{a}}$ & 1.41 & 4.80 & 2.33 & 0.90 \\
\hline High Impulsivity & 0.00 & 1.00 & 0.28 & 0.45 \\
\hline Biological Parents $_{\mathrm{t}-1}$ & 0.00 & 1.00 & 0.31 & 0.45 \\
\hline Parent(s) on Welfare t-1 & 0.00 & 1.00 & 0.13 & 0.31 \\
\hline Family Income $(\$ 1000 \mathrm{~s})_{\mathrm{t}-1}$ & 0.06 & 260.00 & 8.33 & 15.32 \\
\hline Missing Parent Report $\mathrm{t}_{\mathrm{t}-1}$ & 0.00 & 1.00 & 0.15 & 0.36 \\
\hline Self-Reported Risk Taker ${ }_{\mathrm{t}-1}$ & 0.00 & 1.00 & 0.67 & 0.45 \\
\hline \multicolumn{5}{|c|}{ Variables Specific to Perceived Risk of Arrest Models } \\
\hline Violence Perceived Risk of Arrest $t_{t}$ & 0.00 & 100.00 & 43.60 & 34.70 \\
\hline Theft Perceived Risk of Arrest $t_{t}$ & 0.00 & 100.00 & 46.60 & 36.40 \\
\hline Prior Violence Perceived Risk of Arrest $t_{t-1}$ & 0.00 & 100.00 & 44.11 & 35.09 \\
\hline Prior Theft Perceived Risk of Arrest $\mathrm{t}_{-1}$ & 0.00 & 100.00 & 50.30 & 36.43 \\
\hline \multicolumn{5}{|l|}{ Experienced Certainty $_{t}$} \\
\hline$>.00-.05$ & ng 0.00 to & 1.00 & 0.12 & 0.32 \\
\hline nive.06-y.25 Wisconsin-Madison (cid & olio.eo Lib & Info 1.00 & $(0.11294), 1$ & lato.31c \\
\hline $.26-1.0$ & 0.00 & 1.00 & 0.11 & 0.31 \\
\hline \multicolumn{5}{|l|}{ Unsanctioned Offenses $_{\mathrm{t}}$} \\
\hline Low Offending $(0-2)$ & 0.00 & 1.00 & 0.10 & 0.30 \\
\hline Medium Offending (3-9) & 0.00 & 1.00 & 0.10 & 0.30 \\
\hline High Offending $(\geq 10)$ & 0.00 & 1.00 & 0.13 & 0.34 \\
\hline Peer Violence $_{t}$ & 1.00 & 5.00 & 1.93 & 0.91 \\
\hline Peer Theft $t_{t}$ & 1.00 & 5.00 & 1.60 & 0.82 \\
\hline \multicolumn{5}{|l|}{ Variables Specific to Behavior Models, $\mathrm{t}$} \\
\hline Violence & 0.00 & 300.00 & 1.18 & 8.15 \\
\hline Theft & 0.00 & 340.00 & 1.26 & 11.69 \\
\hline Violence Opportunities & 1.00 & 5.00 & 1.93 & 1.19 \\
\hline Theft Opportunities & 1.00 & 5.00 & 1.26 & 1.42 \\
\hline \multicolumn{5}{|l|}{ Variables Specific to Behavior Models, $\mathrm{t}-1$} \\
\hline Grades & 0.00 & 5.00 & 3.52 & 1.06 \\
\hline Employed & 0.00 & 1.00 & 0.37 & 0.47 \\
\hline Not in School & 0.00 & 1.00 & 0.03 & 0.16 \\
\hline Prior Violence (logged) & 0.00 & 6.69 & 0.31 & 0.79 \\
\hline Prior Theft (logged) & 0.00 & 6.90 & 0.32 & 0.80 \\
\hline Police Contact & 0.00 & 52.00 & 0.59 & 2.09 \\
\hline Violence Perceived Risk of Arrest & 0.00 & 5.00 & 2.04 & 1.69 \\
\hline Violence Excitement & 0.00 & 5.00 & 0.63 & 1.24 \\
\hline Violence Coolness & 0.00 & 5.00 & 0.73 & 1.19 \\
\hline Theft Perceived Risk of Arrest & 0.00 & 5.00 & 2.37 & 1.77 \\
\hline Theft Excitement & 0.00 & 5.00 & 0.44 & 0.73 \\
\hline Theft Coolness & 0.00 & 5.00 & 0.51 & 0.91 \\
\hline
\end{tabular}

Note: Sample sizes for dependent variables differ slightly due to a few missing values. Pooled waves $3-5, \mathrm{~N}=$ 3,582. $\mathrm{SD}=$ standard deviation. For independent variables, sample size is constant due to conditional mean imputation.

a Total number of crimes reported to police in 1984 per 10 residents by neighborhood. 
borhood disorganization, we factor-analyzed six 1990 census block group variables, identified two dimensions found in previous studies, and created two scales: residential stability and concentrated disadvantage. We treat proportion black in the census block group as a distinct variable. Crime rate 1984 is the total number of crimes reported to police in 1984 per 10 residents by neighborhood. For our individual background variables, female, age, family structure, black, and Hispanic origin are taken from youth reports, while income and welfare are taken from parent reports. For the 11 percent missing parent reports, we impute the mean and use a dummy variable to control for the effect of missing values. Following studies of impulsivity and antisocial behavior, high child impulsivity is measured by four items from parent reports in 1988 summed to form an index with reliability $\alpha=.72$.

Our key concepts - risks, returns, and opportunities - are measured from youth reports. ${ }^{7}$ For models of perceived risk of arrest, we use two sets of variables to measure experiential learning. First is experienced certainty, measUured by the Hatio or the riurnber fin timeslever arrested or questioned by police to the number of all self-reported crimes in the past year. ${ }^{8}$ Following Horney and Marshall (1992), we create three dummy variables to represent three intervals derived from the distribution of the data (>.00-.05, .06-.25, .26-1.0), with non-offenders (zero self-reported crimes) as the omitted category (see Table 1). The dummy variables will allow us to test the updating hypothesis that experienced certainty is positively and monotonically related to perceived certainty. Second are unsanctioned offenses, measured by the number of self-reported offenses committed by those who have not been questioned or arrested by police. We again categorize these variables into three intervals (0-2, 3-9, 10 and higher) based on the distribution of the data, create three dummy variables (with non-offenders

${ }^{7}$ Measures in the rational choice section of the DYS were designed by Ross Matsueda and Irving Piliavin, in collaboration with David Huizinga and Finn Esbensen.

${ }^{8}$ We also constructed this variable using arrests in the past year, to correspond to the time frame of selfreports, and found similar results. again the omitted category), and test for a negative monotonic relationship. Our risk models also include three-item indexes of peer theft ( $\alpha$ $=.82)$ and peer violence $(\alpha=.84)$ to capture information from the experience of friends.

For models of theft and violence, we use four sets of variables to measure perceived risks and rewards, perceived opportunities, risk preferences, and opportunity costs. Our central explanatory variables are perceived costs and returns to crime. For each cost and return, we measure perceived utility by asking how good or bad it would be and subjective probability by how likely it would result from theft or violence. Thus, our costs are the probability of arrest for committing theft (violence) weighted by how good or bad an arrest would be. Similarly, our rewards are the probability of getting excitement from theft (violence) and the probability of being seen as cool from committing theft (violence), each weighted by how good or bad excitement or coolness would be. ${ }^{9}$ Note that for theft, we are controlling for monetary rewards to crime by specifying a monetary amount (\$10) in the question.

Eblito neasure crime opportunities, ave use indi-t: ilcators of perceived opportunities to commit otheft:(vialence) and get away with it (e.g., Piliavin et al. 1986; Hagan and McCarthy 1997). The clause, "get away with it," implies that, consistent with a rational choice model, opportunities are capturing an interaction between perceived opportunities to commit crime and the perceived certainty of arrest. ${ }^{10}$ We measure risk preference (or taste for risk) in a straightforward way: "Do you agree with the statement, 'I like to do daring things'?” (e.g., Hagan, Simpson,

\footnotetext{
${ }^{9}$ We also examined alternate measures of costs (chances you would end up in jail or training school, chances your parents would find out) and rewards (chances you would feel good about yourself), which are related to theft and violence but not quite as strongly as those we report.

10 The probability of getting away with crime, $\mathrm{P}($ Crime $\cap-$ Arrest $)$, is related to the certainty of arrest, $\mathrm{P}$ (Arrest|Crime), according to the following equation: $\mathrm{P}($ Crime $\cap-$ Arrest $)=\mathrm{P}($ Crime $)[1-$ $\mathrm{P}($ Arrest $\mid$ Crime $)]$, where the second term is the probability of crime times one minus the perceived certainty of arrest. This assumes that the model conditions on propensity to deviate, so that $\mathrm{P}$ (Crime) is perceived objective opportunity.
} 
and Gillis 1987). We use two measures of opportunity costs of crime: grades (measured by selfreported grade point average) and employment (measured by a dummy variable indicating whether or not the youth is employed). We include a dummy variable for being out of school (and thus, missing values on grades).

To distinguish instrumental from expressive crimes, we estimate separate models of theft and violence. For models of risk perceptions, our dependent variable is the probability of being picked up by the police for theft (violence), measured on a probability scale ranging from 0 to 100 incremented by intervals of 10 . Testretest correlations (not shown), which confound true change with unreliability, show greater change in risk perceptions for younger cohorts (.25 for 11 year olds) than older cohorts (.45 for 15 year olds), as expected. The average of about .33 probably reflects moderate true change and reasonable reliability. For example, if true stability $\rho_{21}$ were .50 and reliability $\rho_{x x}$ were .70 , we would expect a test-retest correlation $r_{21}$ of .35 , since $r_{21}=\rho_{21} \rho_{\mathrm{xx}}^{1 / 2} \rho_{\mathrm{xx}}{ }^{1 / 2}$ (for temporal distributions, see our $A S R$ Online Suppiement to this article at http://www2.asanet.org/ journals/asr/2005/toc049.html). For models of theft (violence), our dependent variable is a sum of seven (three) standard self-report items summed to provide a count of offenses for the past year (see Appendix). We control for prior theft (violence) in all models. ${ }^{11}$

\section{MODELS OF BAYESIAN LEARNING AND PERCEIVED RISK OF ARREST}

To test our Bayesian updating model of perceived risk of arrest, we specify a substantive model diagrammed in Figure 1. This model controls for exogenous neighborhood variables (concentrated disadvantage, residential mobility, percent black, and the crime rate in 1984) and individual characteristics (age, sex, race, family structure, impulsivity, and risk preference). It specifies perceived risk at time $t$ as a

${ }^{11}$ We logged the lagged dependent variable so the functional form approximates linearity (and add one to each observed value before logging to deal with zero values). This results in stronger lagged effects and more conservative estimates of effects of other variables. function of prior risk at time $t-1$, and then introduces three pieces of new information, each measured at $t-1$, to test the updating hypothesis: experienced certainty, unsanctioned offenses, and delinquent peers.

\section{STATISTICAL MODELS: RANDOM-EFFECTS TOBIT MODELS}

To estimate models of perceived risk of arrest, we use random-effects Tobit models with lagged regressors. Our models can be specified as follows. If we let $y_{i t}$ be our observed measure of perceived risk of arrest for person $i$ at time $t$, our models take the following form:

$$
\begin{gathered}
y^{*}{ }_{i t}=\alpha_{i}+z_{i} \gamma+x_{i t-1} \beta+y_{i t-1} \rho+\varepsilon_{i t} \\
\text { where } y_{i t}=\left\{\begin{array}{c}
\tau_{u} \text { if } y^{*}{ }_{i t} \geq \tau_{u} \\
y^{*}{ }_{\text {it }} \text { if } \tau_{u}>y^{*}{ }_{i t}>\tau_{l} \\
\tau_{l} \text { if } y_{i t}^{*} \leq \tau_{l}
\end{array}\right.
\end{gathered}
$$

and $\alpha_{i}$ is unobserved heterogeneity, which varies across individuals but not time, $\gamma, \beta$, and $\rho$ are coefficients, $y_{i t}^{*}$ is a latent continuous (unbounded) measure of perceived risk, $z_{i}$ is a vector of time-invariant covariates, $x_{i t-1}$ is a vector of time-varying lagged covariates, $y_{i t-1}$ is observed lagged perceived certainty, $\varepsilon_{i t}$ is a disturbance term (assumed normal with constant variance), and $\tau_{u}$ and $\tau_{l}$ are upper and lower thresholds, respectively.

Our Tobit models address violations of three key assumptions of the usual linear regression model. First, the dependent variable, perceived risk, is measured in probabilities, which bound the scales at zero and 100. Consequently, linear models will yield downwardly biased coefficient estimates due to floor and ceiling effects when the data clump at zero or 100. Therefore, we use a two-limit censored regression or Tobit model, which takes into consideration the propensity to be censored at zero or unity (see Maddala 1983; Long 1997). ${ }^{12}$ Second, our pooled person-year

12 We treat the floor and ceiling effects as generated by problems in the measurement scale, rather than generated by a true probability scale that allows negative values or values exceeding unity. We examine the possibility that the process generating nonbounded values differs from the process generating 
data are dependent across individuals due to unobserved heterogeneity. We use random effects models, which assume $\alpha_{i}$ is uncorrelated with $z_{i}$ and $x_{i t-1}$, to correct for such dependence and obtain consistent and asymptotically efficient estimates. ${ }^{13}$ Third, our independent (experienced certainty, and peer delinquency) and dependent variables (perceived certainty) could be reciprocally related, creating an endogeneity problem. Therefore, we use a threewave panel model with a lagged endogenous predictor (prior perceived certainty), $y_{i t-1}$, to control for stability or state dependence in our outcome variable, and lagged time-varying covariates, $x_{i t-1}$, to ensure that the temporal specification of our models is consistent with our theoretical specification. Our randomeffects model helps address potential bias in the estimate of the effect of $y_{i t-1}$, and therefore, other effects as well, by building in equal-correlated (regardless of lag) autocorrelated disturbances.

\section{ESTIMATES of PARAMETERS OF PERCEIVED RISK MODELS}

Table 2 presents estimates of our models of experiential learning and perceived risk of arrest for theft and violence. Model I (columns 1 and 2 ), our reduced-form equation, reveals that females and younger respondents perceive a higher risk of arrest for both theft and violence (lines 2 and 3). On average, females believe the chances of arrest for theft are eleven percentage points higher than do males, and for violence, seven points higher (e.g., Blackwell and Eschholz 2002). Each year of age is associated with a decrease of four percentage points in

variation in positive probabilities using Cragg's (1971) model (Greene 2003); see ASR Online Supplement to this article (http://www2.asanet.org/ journals/asr/2005/toc049.html). On criticisms of the Tobit model, see Raftery (2001) and Maddala (1983).

${ }^{13}$ The Tobit model is not robust to violations of assumptions of normally distributed and homoscedastic disturbances. Thus, we examine these assumptions in sensitivity analyses (see ASR Online Supplement). We also examine the robustness of assuming $\alpha_{i}$ is uncorrelated with $z_{i}$ and $x_{i t-1}$, of using $y_{i t-1}$ versus $y^{*}{ }_{i t-1}$ as our endogenous regressor (see Wooldridge 2002), and of allowing serially correlated errors in the presence of a lagged endogenous predictor. perceived risk for theft and one percentage point for violence. Youth without siblings perceive a lower risk of arrest for violence; the effect is non-significant for theft (line 4). With one exception, our neighborhood contextual variables fail to exert significant effects on certainty, probably because we sampled the most disorganized and high crime neighborhoods. The exception is residential stability, which is associated with lower perceived risk of arrest for theft (line 5).

Model II (columns 3 and 4, Table 2), which adds our lagged control variables, nearly doubles the pseudo- $\mathrm{R}^{2}$ for both theft and violence (compare Models I and II), and reveals two significant effects. ${ }^{14}$ First, on average, respondents who report a preference for risk perceive a lower risk of getting arrested for both theft and violence (line 9). Second, the one-year lagged effects of perceived risk of arrest are substantial, confirming the importance of controlling for stability or state dependence (line 10).

Model III (columns 5 and 6, Table 2) adds our experiential learning variables (nearly doubling the pseudo- $\mathrm{R}^{2} \mathrm{~s}$, to .11 for violence, and .26 for theft and tests aur Bayesian learning hypothe-d: ses. We turn first to experienced certainty (the rate of arrest per offense) and find evidence for updating: using a joint test, we reject the null hypothesis that, net of prior perceived risk, experienced certainty has no effect on perceived risk for theft $\left(\chi^{2}=23.74 ; \mathrm{df}=3 ; p<.001\right)$ and violence $\left(\chi^{2}=26.34 ; \mathrm{df}=3 ; p<.001\right)$. The significant negative coefficients (lines 11-13) support the "shell of illusion" hypothesis 4 , in which naïve individuals who have neither offended nor been arrested will overestimate the certainty of arrest relative to arrested offenders, and not the gambler's fallacy (in which coefficients would be positive).

Moreover, the three dummy variables exhibit a monotonic relationship with certaintythat is, as hypothesized from Bayesian learning, as one moves from low experienced certainty to high, perceived certainty increases monotonically, $\beta_{1}<\beta_{2}<\beta_{3}$, (lines 11-13, Table 2). This is shown graphically in Figure 2 (compare bars

${ }^{14}$ The pseudo- $\mathrm{R}^{2}$ is the variance of the predicted conditional mean to the variance of the dependent variable and is bounded by zero and one (Greene 2002:E21-12). 


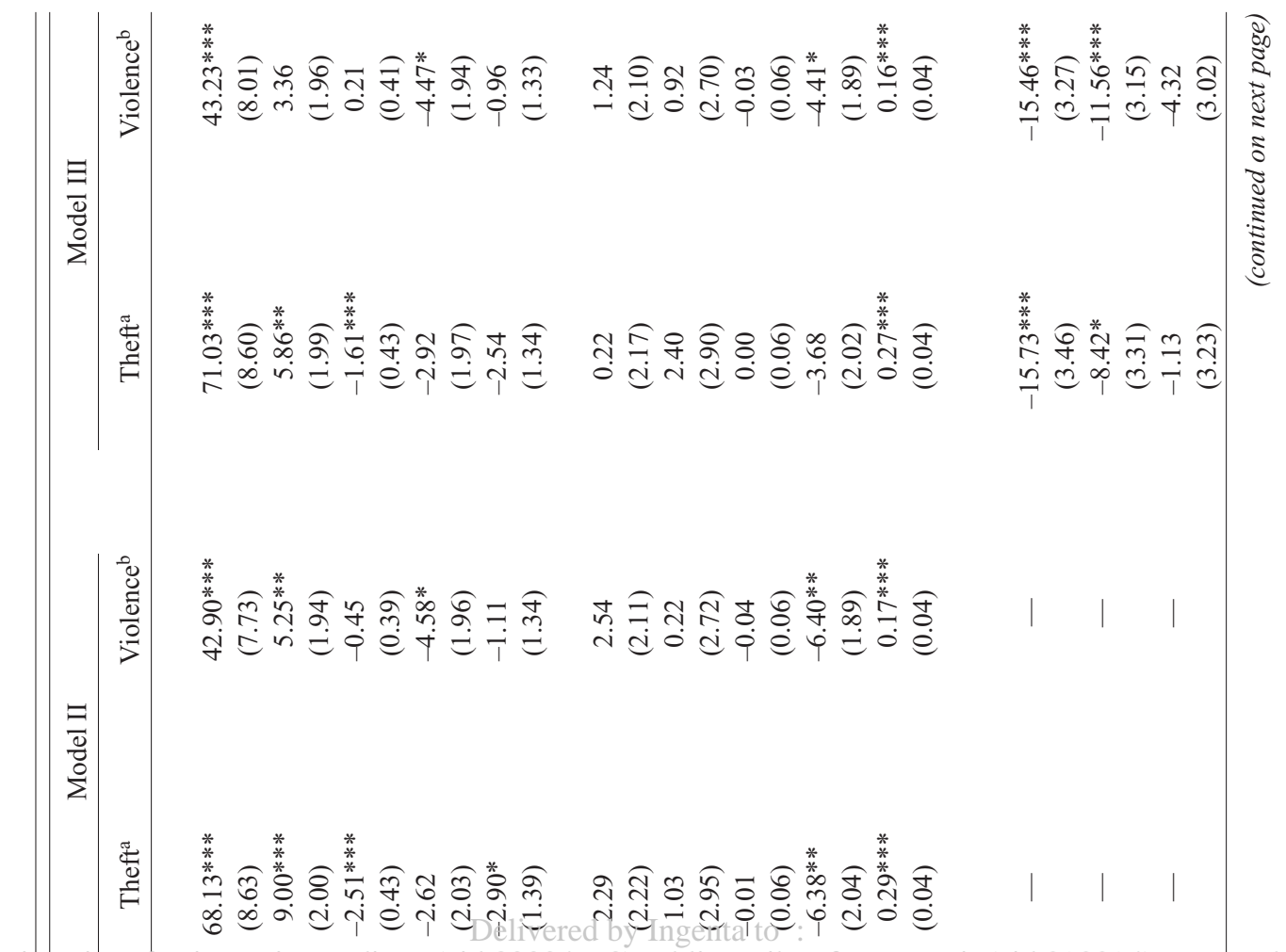

University of Wisconsin-Madison (cid 80004773), Ebling Lib Info Res Unit (cid 292294), matpueda

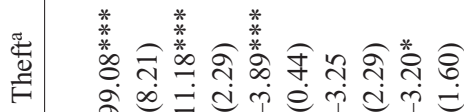




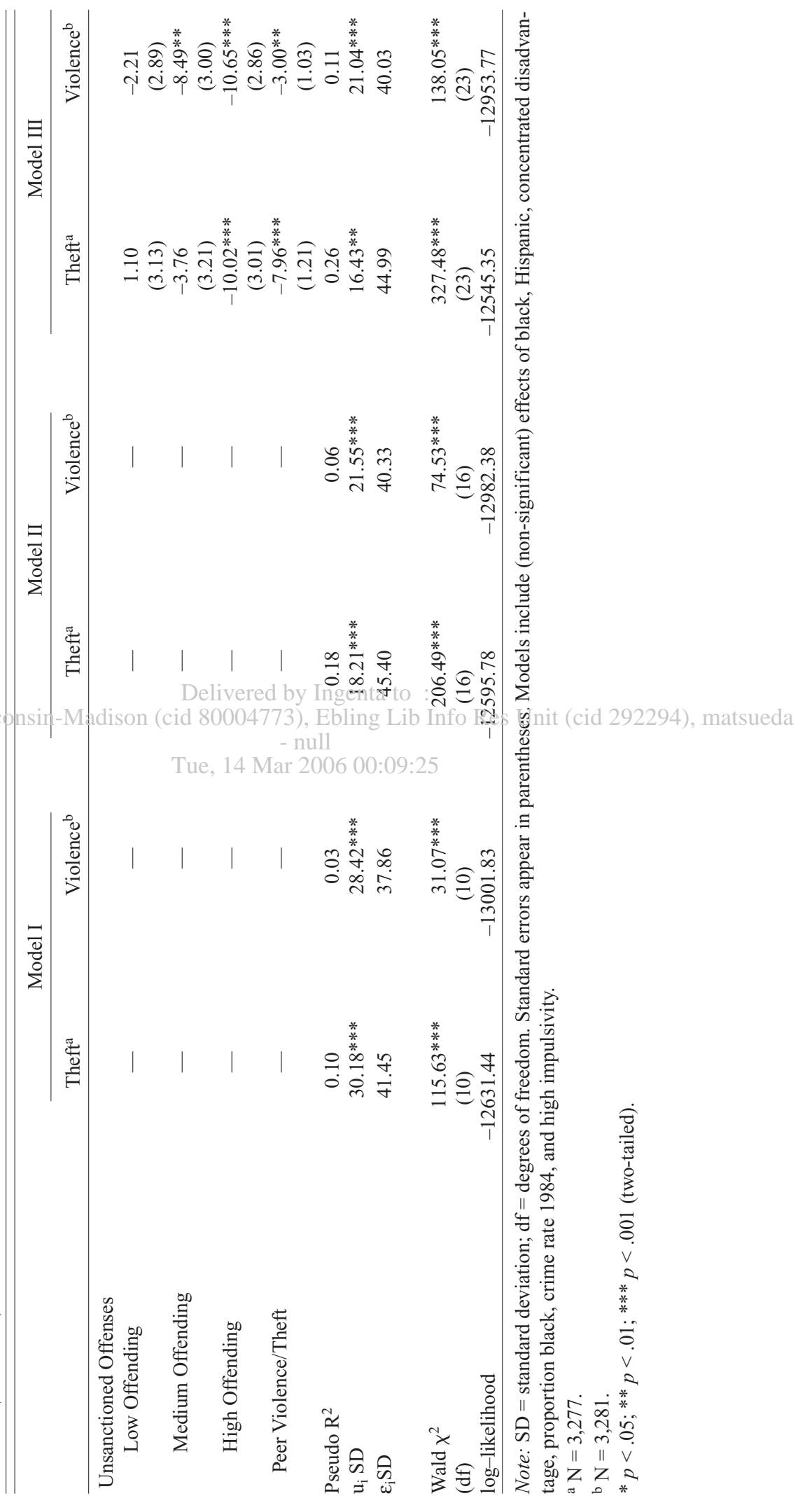




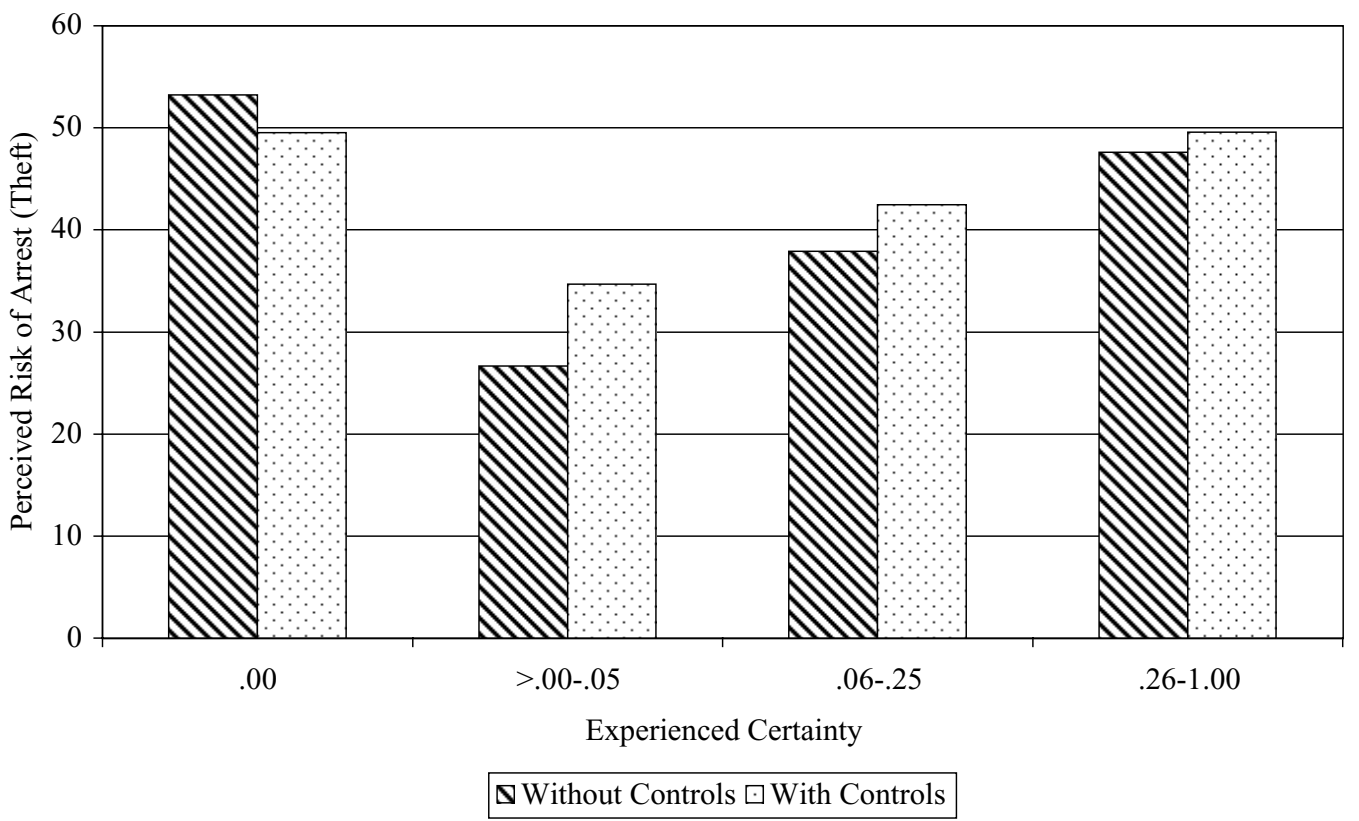

Delivered by Ingenta to

University of Wisconsin-Madison (cid 80004773), Ebling Lib Info Res Unit (cid 292294), matsueda - null

Tue, 14 Mar $\mathbf{B} 06$ 00:09:25

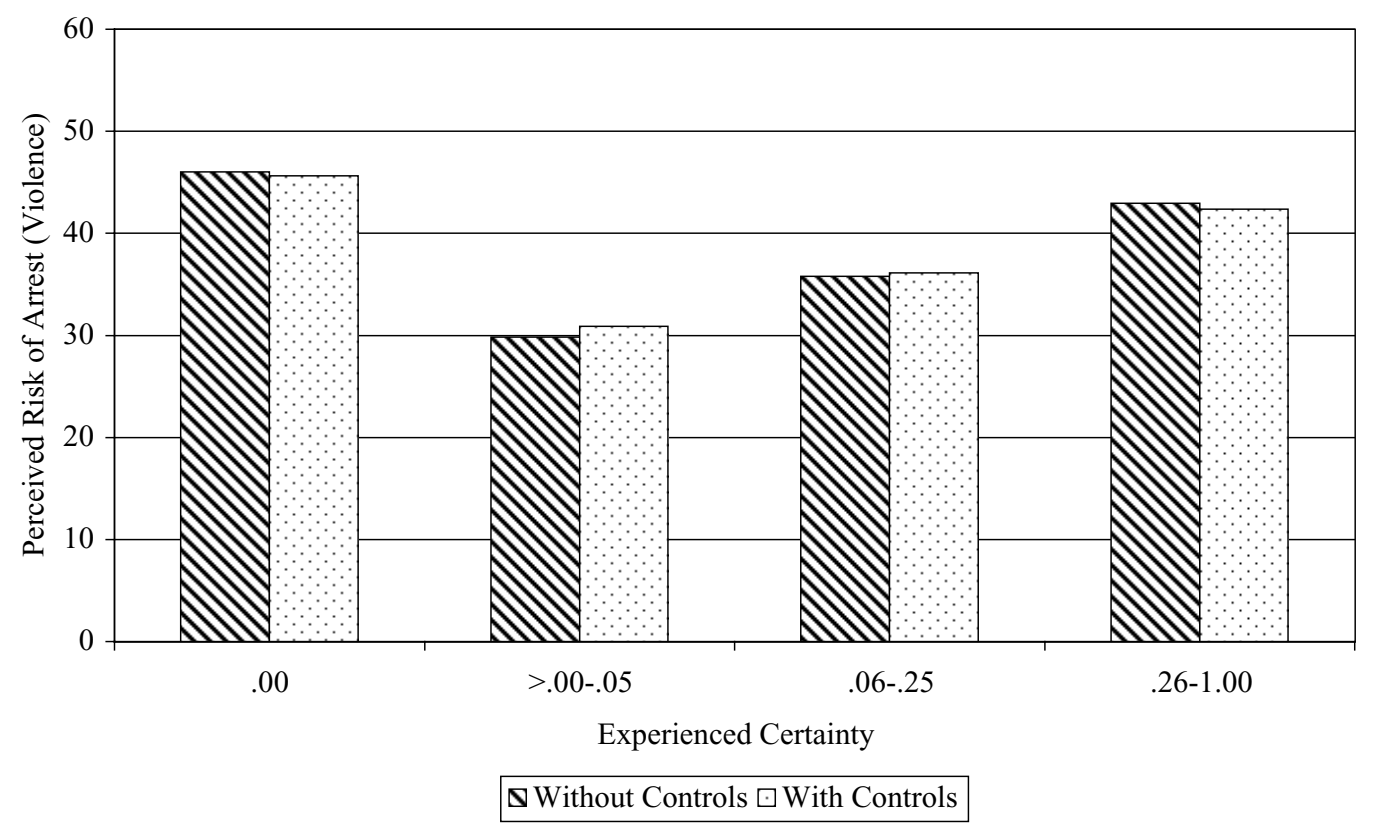

Figure 2. Predicted Perceived Risk of Arrest by Experienced Certainty for (A) Theft and (B) Violence 
2-4 for both $2 \mathrm{~A}$ and $2 \mathrm{~B}$ ), which graphs the predicted values of perceived risk by experienced certainty. These differences are statistically significant: a joint test rejects the null hypothesis that the coefficients are equal $\left(\beta_{1}\right.$, $\left.=\beta_{2},=\beta_{3}\right)$ for theft $\left(\chi^{2}=14.59 ; \mathrm{df}=2 ; p<\right.$ $.001)$ and violence $\left(\chi^{2}=10.27\right.$; df $=2 ; p<$ $.001)$. As expected, the coefficient for the lowest experienced certainty category $(>.00-.05)$ has the biggest negative effect: those who have gotten away with their crimes perceive the certainty of arrest for violence and theft as 15 points lower than naïve youth (line 11). Relative to naïve individuals, those in the middle category (.06-.25) of experienced certainty perceive arrest certainty as 8 points lower for theft and 12 points lower for violence (line 12). Those in the highest experienced certainty category (.26-1.0) - the most frequently arrested per crime - have the smallest coefficient, which is not significantly different from naïve youth (line 13). Thus, naïve individuals most closely resemble the group with the highest rate of arrests per crime (compare bars 1 and 5 in Figures $2 \mathrm{~A}$ and $2 \mathrm{~B}$ ). This overall pattern of results is consistent with those of Horney and Marshall's (1992) study of convicted felons, and it supports our hypothesis of Bayesian learning.

We turn now to the effect of unsanctioned offenses, which are captured with three dummy variables representing categories of offending from low to high. Our omitted category again is naïve individuals who have neither offended nor been arrested. We again find evidence for updating: using a joint test, we reject the null hypothesis that, net of prior perceived risk, unsanctioned offenses have no effect on perceived risk for theft $\left(\chi^{2}=12.94 ; \mathrm{df}=3 ; p<.01\right)$ and violence $\left(\chi^{2}=17.22 ; \mathrm{df}=3 ; p<.001\right)$. Thus, we do not find support for the hypothesis that youth ignore new information, and instead anchor their estimates in initial values, or the gambler's fallacy, in which youth believe they are "due" for an arrest. We find support for the "shell of illusion" hypothesis for violence: Each of the three coefficients for offending is negative, indicating that naïve individuals have higher risk perceptions than unsanctioned offenders (lines 14-16, column 6, Table 2). For theft, high and medium offending dummy variables are negative. However, negative medium offend- ing dummy variables and the positive low offending coefficient are not significant.

We find support for the Bayesian learning hypothesis that, on average, as unsanctioned offenses increase, certainty of arrest declines monotonically: For both theft and violence, our coefficients decrease (become more negative) as unsanctioned offenses move from low to high, $\beta_{1}>\beta_{2}>\beta_{3}$ (lines 14-16, Table 2). For both behaviors, the differences among the categories are statistically significant: a joint test rejects the null hypothesis that the coefficients are equal $\beta_{1}=\beta_{2}=\beta_{3}$ for theft $\left(\chi^{2}=9.16\right.$; df $=2 ; p<.05)$ and violence $\left(\chi^{2}=6.28 ; \mathrm{df}=2\right.$; $p<.05)$. Compared to naïve individuals, high offenders (10 or more offenses) perceive the risk of arrest for violence about ten points lower, and medium offenders (3-9 offenses) about eight points lower. Low offenders are two points lower, but the effect is not significant (line 14). For theft, high offenders are 10 points lower than naïve youth (line 16), and medium offenders are four points lower than naïve youth (line 15), but the latter coefficient is not significant. Neither is the low offending coefficient. Naïve youth most closely resemble (lov unsanetioned offenders for both theft and violence. Again, the overall pattern of results for unsanctioned offenses is consistent with the hypothesis of Bayesian learning.

We find support for the Bayesian learning hypothesis that delinquency by peers will be associated with lower perceptions of certainty of arrest. Net of personal experience variables, a unit change in our delinquent peer measure is associated with an eight percent decrease in perceived risk of arrest for theft and a three percent decrease for violence (line 17, Table 2). Thus, information from peers is not completely swamped by the more vivid personal experiences with crime and arrest. Finally, we find that, consistent with updating, prior perceived risk maintains a significant effect on updated risk perceptions (line 10), even net of new information. The coefficients diminish only slightly between Models II and III.

In sum, the data support a Bayesian learning view of formation of perceived arrest risk and Tittle's "shell of illusion" hypothesis. Of course, evidence of such learning is impressive for a rational choice model only if risk per- 


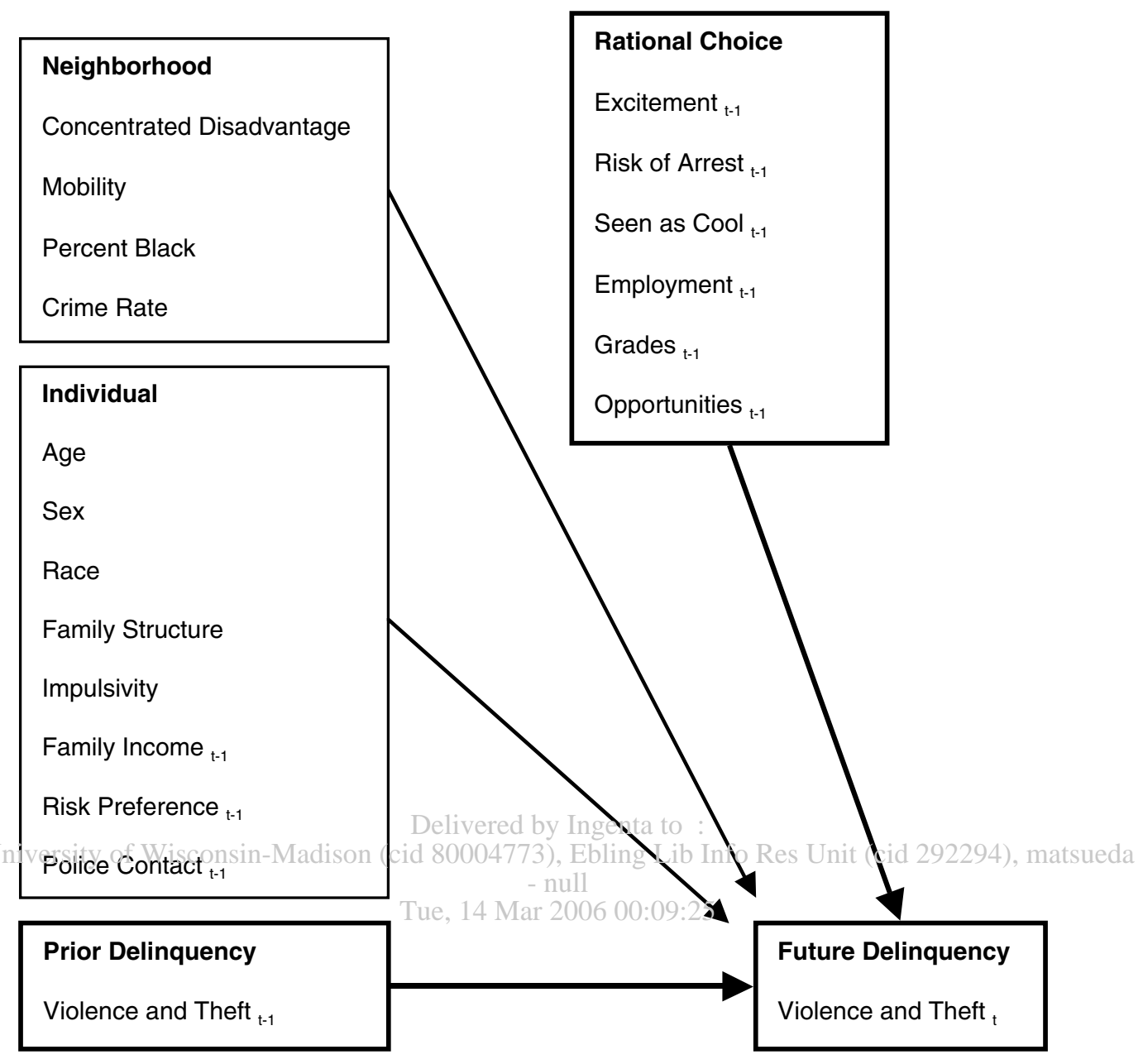

Figure 3. Rational Choice Models of Violence and Theft

ceptions are used in behavioral decisions - to which we now turn.

\section{MODELS OF RATIONAL CHOICE, THEFT, AND VIOLENCE}

We specify a conceptual model of rational choice and criminal behavior diagrammed in Figure 3. The model controls for exogenous neighborhood variables and individual characteristics, specifies theft or violence at time $t$ as a function of prior theft or violence at time $t-1$, and then introduces our lagged variables capturing opportunity costs (grade point average and employment), and our perceptual rational choice variables (risks, rewards, and opportunities). Perceived opportunity is meas- ured at time $t$, contemporaneously with our outcome of theft and violence, in part because opportunities operate principally within the situation. $^{15}$

\section{STATISTICAL MODELS: RANDOM-EFFECTS NEGATIVE BINOMIAL MODELS}

Because our measures of theft and violence are counts of offenses, treating them as con-

\footnotetext{
${ }^{15}$ This could create endogeneity between opportunities and theft (violence) — as criminal acts could alter perceptions of crime opportunities - resulting in an upwardly biased estimated effect. This implies that our test of risks and rewards is conservative.
} 
tinuous and using linear models can yield inconsistent and inefficient estimates of parameters. A better approach assumes the counts of delinquency are generated from a Poisson distribution. We estimated a Poisson regression model and, as expected, found overdispersion-the variance exceeded the mean count of delinquency - which, if ignored, can result in inefficient estimates of coefficients and downwardly biased standard errors (Long 1997). ${ }^{16}$ Consequently, we turned to a negative binomial model, which allows the rate of delinquency to vary across individuals, and therefore, the variance to exceed the mean. Formal likelihood ratio tests show a better fit for the negative binomial model for both theft $\left(\chi^{2}=\right.$ $13,498 ; \mathrm{df}=1 ; p<.001)$ and violence $\left(\chi^{2}=\right.$ 12,082; $\mathrm{df}=1 ; p<.001$ ) (for details, see Figure $\mathrm{S} 1$ in our ASR Online Supplement).

In estimating our negative binomial model, we found dependence in observations across individuals, which can result in inefficiency and biased standard errors; we therefore estimated a random-effects negative binomial model. Formal likelihood ratio tests show that the random-effects model fit the clata better than a pooled model (that ignores the dependence) for both theft $\left(\chi^{2}=187.52 ; \mathrm{df}=1 ; p^{<}\right.$ $.001)$ and violence $\left(\chi^{2}=172.88 ; \mathrm{df}=1 ; p<\right.$ $.001)$. Therefore, we present the random effects negative binomial specification estimated by maximum likelihood (Hausman, Hall, and Girliches 1984). This model allows for overdispersion in the Poisson model with the inclusion of a parameter $\delta$ and then layers a random individual effect onto the negative binomial model by assuming $\delta_{i} /\left(1+\delta_{i}\right)$ follows a beta distribution with parameters a and $\mathrm{b}$ (see $A S R$ Online Supplement). Unlike the random effects Poisson model, this model allows the rate to vary across individuals and time (even if the $\mathrm{x}_{i t} \mathrm{~s}$ are constant).

Our negative binomial models, like our Tobit models, include lagged time-varying covariates $x_{i t-1}$ to ensure that the temporal specification

16 Overdispersion can arise from a variety of sources, including unobserved heterogeneity (e.g., omitted variables, such as genetics, early socialization, or structural ties) that affect individual propensity to commit crime, clustering in the data (in our case, neighborhoods and families), positive contagion, and rate dependence (see McCullagh and Nelder 1997; Barron 1992). of our models is consistent with our theoretical specification and include the lagged endogenous predictor (prior perceived certainty) $y_{i t-1}$ to control for stability or state dependence in theft and violence. The random effects specification helps overcome potential bias in the estimate of the effect of $y_{i t-1}$ (and therefore, other estimates) by allowing for approximately equal-correlated autocorrelation among disturbances (Hausman et al. 1984).

\section{ESTIMATES OF PARAMETERS OF CRIMINAL BEHAVIOR MODELS}

Table 3 presents estimates of our random-effects negative binomial models of theft and violence. Model I (columns 1 and 2) presents coefficients of our exogenous control variables. As expected, we find that males and high impulsive individuals engage in substantially more theft and violence (lines 2 and 8). Older youth report slightly more violence but not more theft (line 3). In our sample, compared to whites, blacks engage in substantially more violence but not maore theft, whereas Hispanics engage in slightly more of each (lines 4 and 5). Of our neighborhood yariables, only the 1984 crime rate affects theft and violence (line 7). Among our time-varying lagged control variables, biological parents exert a negative effect that is significant for theft but not violence (line 9), and income is negatively associated with violence but not theft (line 10). As expected, net of our background variables, prior violence and theft exert strong lagged effects on future violence and theft, respectively (line 12). This highlights the importance of controlling for state dependence, which helps control for unobserved heterogeneity in our models. ${ }^{17}$

Model II (columns 3 and 4, Table 3 ) adds our rational choice variables, including risk preference, opportunity costs, and perceived costs and rewards. As hypothesized, youth who like to do daring things are substantially more likely to steal and fight (line 14). This is consistent with our rational choice model, which predicts that risk-averse youth will avoid risky behaviors

${ }^{17}$ We are following previous research on deterrence and crime by controlling for prior crime and arrest. We find similar results when we control for experienced certainty and unsanctioned offenses. 
Table 3. Random Effects Negative Binomial Models of Violence and Theft (Waves 3-5)

\begin{tabular}{|c|c|c|c|c|c|c|}
\hline & \multicolumn{2}{|c|}{ Model I } & \multicolumn{2}{|c|}{ Model II } & \multicolumn{2}{|c|}{ Model III } \\
\hline & Theft $^{\mathrm{a}}$ & Violence $^{b}$ & Theft $^{\mathrm{a}}$ & Violence $^{b}$ & Theft $^{\mathrm{a}}$ & Violence $^{b}$ \\
\hline \multicolumn{7}{|l|}{ Variables } \\
\hline Intercept & $\begin{array}{l}-1.63 * * * \\
(0.41)\end{array}$ & $\begin{array}{l}-2.98 * * * \\
(0.11)\end{array}$ & $\begin{array}{l}-1.27^{* *} \\
(0.48)\end{array}$ & $\begin{array}{l}-2.27 * * * \\
(0.48)\end{array}$ & $\begin{array}{l}-1.62 * * * \\
(0.48)\end{array}$ & $\begin{array}{l}-2.78 * * * \\
(0.48)\end{array}$ \\
\hline Female & $\begin{array}{l}-0.58 * * * \\
(0.11)\end{array}$ & $\begin{array}{l}-0.59 * * * \\
(0.10)\end{array}$ & $\begin{array}{l}-0.45^{* * *} \\
(0.11)\end{array}$ & $\begin{array}{l}-0.45^{* * *} \\
(0.10)\end{array}$ & $\begin{array}{l}-0.41 * * * \\
(0.11)\end{array}$ & $\begin{array}{l}-0.39 * * * \\
(0.10)\end{array}$ \\
\hline Age & $\begin{array}{c}-0.03 \\
(0.02)\end{array}$ & $\begin{array}{l}0.06^{* *} \\
(0.02)\end{array}$ & $\begin{array}{c}-0.04 \\
(0.02)\end{array}$ & $\begin{array}{c}0.02 \\
(0.02)\end{array}$ & $\begin{array}{l}-0.06^{* *} \\
(0.02)\end{array}$ & $\begin{array}{c}0.02 \\
(0.02)\end{array}$ \\
\hline Black & $\begin{array}{c}-0.11 \\
(0.17)\end{array}$ & $\begin{array}{l}0.61 * * * \\
(0.17)\end{array}$ & $\begin{array}{c}-0.13 \\
(0.17)\end{array}$ & $\begin{array}{l}0.63 * * * \\
(0.17)\end{array}$ & $\begin{array}{c}-0.20 \\
(0.17)\end{array}$ & $\begin{array}{l}0.49 * * \\
(0.17)\end{array}$ \\
\hline Hispanic & $\begin{array}{c}0.22 \\
(0.14)\end{array}$ & $\begin{array}{c}0.21 \\
(0.15)\end{array}$ & $\begin{array}{c}0.21 \\
(0.14)\end{array}$ & $\begin{array}{c}0.24 \\
(0.15)\end{array}$ & $\begin{array}{c}0.22 \\
(0.14)\end{array}$ & $\begin{array}{c}0.23 \\
(0.15)\end{array}$ \\
\hline Residential Stability & $\begin{array}{c}0.14^{*} \\
(0.07)\end{array}$ & $\begin{array}{c}0.10 \\
(0.07)\end{array}$ & $\begin{array}{l}0.19 * * \\
(0.07)\end{array}$ & $\begin{array}{c}0.13 \\
(0.07)\end{array}$ & $\begin{array}{c}0.18 * \\
(0.07)\end{array}$ & $\begin{array}{c}0.11 \\
(0.07)\end{array}$ \\
\hline Crime Rate, 1984 & $\begin{array}{c}0.14^{*} \\
(0.06)\end{array}$ & $\begin{array}{c}0.12 \\
(0.06)\end{array}$ & $\begin{array}{c}0.15^{*} \\
(0.06)\end{array}$ & $\begin{array}{c}0.11 \\
(0.06)\end{array}$ & $\begin{array}{c}0.15^{*} \\
(0.06)\end{array}$ & $\begin{array}{c}0.11 \\
(0.06)\end{array}$ \\
\hline High Impulsivity & $\begin{array}{l}0.28^{* *} \\
(0.10)\end{array}$ & $\begin{array}{c}0.26^{*} \\
(0.10)\end{array}$ & $\begin{array}{c}0.25^{*} \\
(0.10)\end{array}$ & $\begin{array}{l}0.29 * * \\
(0.11)\end{array}$ & $\begin{array}{c}0.23^{*} \\
(0.10)\end{array}$ & $\begin{array}{l}0.28 * * \\
(0.10)\end{array}$ \\
\hline \multicolumn{7}{|l|}{ Lagged Variables, $\mathrm{t}-1$} \\
\hline Biological Parents & $\begin{array}{l}-0.56^{* * *} \\
(0.12)\end{array}$ & $\begin{array}{c}-0.14 \\
(0.12)\end{array}$ & $\begin{array}{l}-0.53^{* * *} \\
(0.12)\end{array}$ & $\begin{array}{c}-0.14 \\
(0.12)\end{array}$ & $\begin{array}{l}-0.53 * * * \\
(0.12)\end{array}$ & $\begin{array}{c}-0.15 \\
(0.12)\end{array}$ \\
\hline Family Income (\$1000’s) & $\begin{array}{c}0.00 \\
(0.00)\end{array}$ & $\begin{array}{l}-0.01 * * \\
(0.00)\end{array}$ & $\begin{array}{c}0.00 \\
(0.00)\end{array}$ & $\begin{array}{l}-0.01 * * \\
(0.00)\end{array}$ & $\begin{array}{c}0.00 \\
(0.00)\end{array}$ & $\begin{array}{l}-0.01 * * \\
(0.00)\end{array}$ \\
\hline Parent(s) on Welfare & $\begin{array}{c}0.19 \\
(0.13)\end{array}$ & $\begin{array}{l}0.26^{*} \\
(0.13)\end{array}$ & $\begin{array}{c}0.19 \\
(0.13)\end{array}$ & $\begin{array}{c}0.22 \\
(0.13)\end{array}$ & $\begin{array}{c}0.17 \\
(0.13)\end{array}$ & $\begin{array}{c}0.21 \\
(0.13)\end{array}$ \\
\hline Prior Behavior (Logged) & $\begin{array}{l}0.22 * * * 8 \\
(0.06)\end{array}$ & $0.20 * * *$ & $0.15^{* *}$ & $0.14 *$ & $\begin{array}{l}0.13 * 29 \\
(0.06)\end{array}$ & $(0.06)$ \\
\hline Police Contact & $\begin{array}{l}0.02 \\
(0.02)\end{array}$ & $\begin{array}{l}0.02 \\
(0.01)\end{array}$ & $\begin{array}{l}0.02 \\
(0.02)\end{array}$ & $\begin{array}{c}0.01 \\
(0.01)\end{array}$ & $\begin{array}{c}0.00 \\
(0.02)\end{array}$ & $\begin{array}{c}0.00 \\
(0.01)\end{array}$ \\
\hline Risk Preference & - & - & $\begin{array}{l}0.36^{* * *} \\
(0.11)\end{array}$ & $\begin{array}{l}0.40 * * * \\
(0.11)\end{array}$ & $\begin{array}{l}0.31 * * \\
(0.11)\end{array}$ & $\begin{array}{l}0.36^{* *} \\
(0.11)\end{array}$ \\
\hline Grades & - & - & $\begin{array}{l}-0.14^{* *} \\
(0.05)\end{array}$ & $\begin{array}{l}-0.15 * * \\
(0.05)\end{array}$ & $\begin{array}{l}-0.10 \\
(0.05)\end{array}$ & $\begin{array}{c}-0.13^{*} \\
(0.05)\end{array}$ \\
\hline Employed & - & - & $\begin{array}{c}0.10 \\
(0.10)\end{array}$ & $\begin{array}{l}0.35 * * * \\
(0.09)\end{array}$ & $\begin{array}{c}0.07 \\
(0.10)\end{array}$ & $\begin{array}{l}0.34 * * * \\
(0.09)\end{array}$ \\
\hline
\end{tabular}

(continued on next page)

like crime, whereas risk-preferring youth will be attracted to crime. Moreover, it underscores the importance of controlling for risk preference when examining costs and rewards.

We turn next to opportunity costs, which are measured by grade point average and employment. Among current students, higher grades are significantly associated with fewer acts of violence and theft (line 15, Table 3). Thus, high achieving students are unlikely to jeopardize their investments in schooling by committing crimes. Employment has no effect on theft, but it has a positive effect on violence (line 16). The latter finding is inconsistent with an opportunity costs mechanism but consistent with previous research on delinquency. Although the positive effect on violence persists when controlling for prior violence and being in school, it may be due to unobserved selection into jobs while a student. We also find that youth who are not attending school - either because they graduated (the majority) or dropped out - and thus have no grades, commit fewer acts of violence and theft on average (line 17).

Turning to our crucial hypotheses concerning perceived costs and rewards, we find support for a rational choice perspective. In contrast to most previous studies of deterrence using panel survey data, we find a significant deterrent effect of arrest (perceived certainty weighted by per- 
Table 3. (Continued)

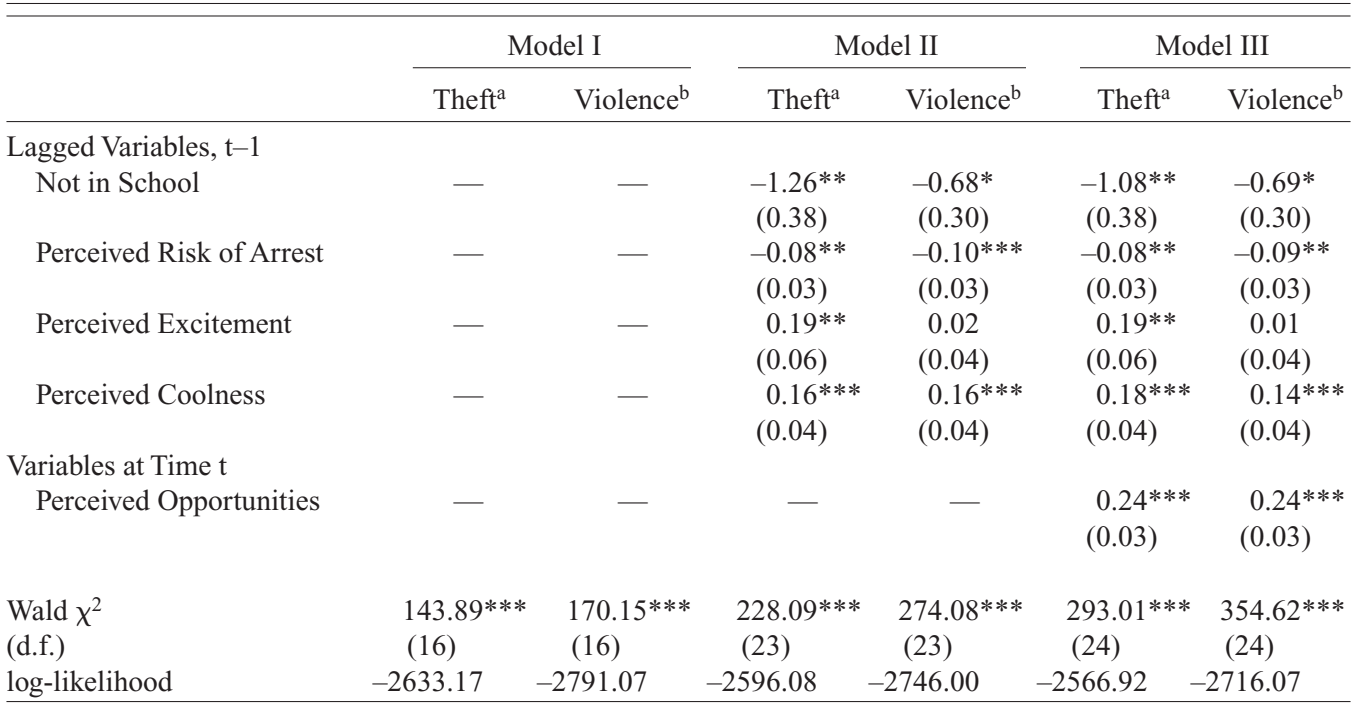

Note: Standard errors appear in parentheses. Models include (non-significant) effects of no siblings, concentrated disadvantage, and proportion black.

${ }^{a} \mathrm{~N}=3,297$.

${ }^{\mathrm{b}} \mathrm{N}=3,298$.

$* p<.05 ; * * p<.01 ; * * * p<.001$ (two-tailed).

\section{Delivered by Ingenta to}

University of Wisconsin-Madison (cid 80004773), Ebling Lib Info Res Unit (cid 292294), matsueda ceived utility) (line 18, Table 3). Moreover, this holds not only for theft but also for violence, supporting McCarthy's (2002) suggestion that violence is often instrumental. Youth who believe they will be caught for their theft or violence (and view arrest as bad), commit fewer acts of theft or violence, on average, in the coming year.

We also find support for the reward side of the rational choice process (e.g., Piliavin et al. 1986). First, we find that the probability of excitement and kicks affects theft but not violence (line 19, Table 3). Youth who expect excitement and kicks (and value excitement) from stealing commit, on average, more acts of theft. This result, combined with the null finding of excitement on violence, supports a model of sneaky thrills from theft (Katz 1988). From a rational choice standpoint, such thrills are psychic rewards from theft and are important in decisions to steal. Second, youth who expect to be seen as cool (and value being seen as cool) if they commit theft or violence tend to commit substantially more acts of theft and violence, on average, in the coming year (line 20). This finding is consistent with ethnographic research and subcultural theories that depict crime as an

alternate way of achieving status within reference groups. Moreover, it suggests that a favorable image from the standpoint of others is an important psychic reward to crime (e.g., Matsueda 1992). ${ }^{18}$

Model III (columns 5 and 6, Table 3) adds criminal opportunities to our models and reveals substantial effects. For both theft and violence, perceived opportunities to commit theft or violence and get away with it substantially increase the likelihood of theft and violence (line 21). The coefficient for each equation is identical in size (.24). Recall that our variable, perceived opportunities to get away with theft or violence, captures an interaction between perceptions of opportunities to commit crime and the certainty of arrest. Thus, including it alters the meaning of our perceived risk effects, which are now approximately main effects in an interaction model. This finding supports a routine activities or criminal opportunities approach interacting with a perceptual rational choice model.

18 The estimates of rational choice coefficients are robust to controls for other variables, such as delinquent peers. 
Finally, we can examine the hypothesis, derived from a limited rationality model, that criminals discount consequences with a longer time horizon, such as formal sanction, while focusing on immediate criminal rewards and opportunities. Standardized coefficients show the relative effects of perceived cost and rewards to be comparable in magnitude. ${ }^{19}$ For theft, the standardized coefficients for excitement (.15), certainty (-.13), and coolness (.18) are similar in absolute value. For violence, the corresponding coefficients for certainty $(-.14)$ and coolness (.17) are similar, while excitement has no effect. Thus, we fail to find support for the discounting hypothesis, and instead we find support for both sides of a rational choice model - costs and returns.

\section{DISCUSSION}

Our results support a Bayesian learning model of perceived risk formation, a rational choice model of criminal behavior, and a deterrence hypothesis of perceived risk of arrest. Previous research on deterrence using surveys of perceived trisk hascyielded disparate findings. Cross-sectional studies of self-reported crime found small deterrent effects, but these studies were criticized because the temporal ordering of crime and perceived certainty contradicted their causal ordering. Panel studies, using lagged effects to resolve this problem, generally found no deterrent effects. Our results contrast sharply with these prior panel studies. We use (1) more refined measures of certainty of arrest based on a probability scale, (2) a large sample of youth in high risk neighborhoods that insures adequate variation in the models' variables, and (3) appropriate random effects negative binomial estimators that overcome bias and inefficiency. Interestingly, cross-sectional vignette studies, which use criminal intentions as the outcome variable (to address issues of causal order), find consistent deterrent effects of perceived risk. While it may be tempting to dismiss the vignette results because of a potential demand effect - respondents who rate a crime

\footnotetext{
${ }^{19}$ Our standardized negative binomial coefficients are $\exp \left(\beta_{k} s_{k}\right)-1$, where $\beta_{k}$ is the $\mathrm{k}$-th coefficient and $s_{k}$ is the standard deviation of the k-th independent variable (Long 1997).
}

scenario as certain of arrest probably understate their intentions to commit the crime-our panel models of self-reports provide similar results. Future research on perceived risk using both self-report outcomes and behavioral intentions is needed to unravel these processes.

Our results are robust to violations of statistical assumptions in our models (see ASR Online Supplement). Nevertheless, at least four caveats are in order. First, the DYS study sampled high risk disorganized neighborhoods, and we have been careful not to generalize to low risk neighborhoods. We can speculate, however, that if our models can be generalized, such neighborhoods have lower rates of delinquency, in part, because the young residents have fewer delinquent peers, think arrest will follow crime due to the shell of illusion, and do not see crime as a way of gaining excitement or being cool. Second, although we discuss cognitive heuristics to illustrate how learning risk perceptions might depart from Bayesian learning, we have not formally tested for heuristics. This would require calibrating our respondents' estimates against a true stanIrdard so we could test for objective bias in updating estimates. indeed, our estinates are not sufficiently calibrated to rule out cognitive heuristics in our risk estimates - we can only rule out the extreme hypothesis that they eliminate a Bayesian form of updating entirely. Third, although our models use strong measures of costs and returns to crime based on ethnographic research, they have not exhausted all possible incentives. For example, we have controlled for the monetary return to crime by specifying a hypothetical amount in our rewards and costs measures, but have not examined variation in monetary returns. Fourth, we have relied on a one-year lagged effect of perceived costs and returns to crime, which may have understated their effects. The pertinent incentives are those perceived at the time a criminal opportunity presents itself, and these may have changed since the measurement in the previous wave (Piliavin et al. 1986).

Our principal finding that criminal acts of violence and theft conform to a rational choice model may surprise sociologists skeptical of rational choice theories for being reductionist, for being relatively simple models laden with heavy assumptions, and for threatening to usurp the traditional domain of the discipline. We suggest that rational choice and institutional theo- 
ries can be complementary. In fact, in most institutional analyses, it may be prudent to begin with an individual-level rational actor model, as a parsimonious point of departure, before identifying the limitations of such a model and moving to complicate matters with more nuanced concepts of structure, preference, and organization (e.g., Weber [1921/1922] 1978). Our results, while based on an individual-level model of action, do not eschew the role of broader institutions and groups in decision making. We find that the educational institution, by inculcating commitments among students, provides an important opportunity cost for offending. Moreover, we find the legal institution, with its dispassionate threats of punitive sanctions, to be an intimate part of criminal decisions through youths' perceptions of the risk of sanction. Perceived risk, in turn, is formed in part by information gleaned from informal peer groups, as well as direct experience with the legal system. We also find that social status within groups, as indicated by the importance of being seen as cool, is a key component of decisions to offend. Thus, institutional arrangements underlie the parameters of our rational choice model.

Finally, our results have some indirect implications for public policy. Although we find a significant deterrent effect of perceived risk on crime, the effect is modest in size. In a model (not reported) that disentangles perceived risk of arrest from the value (severity) of arrest and excludes opportunities, we find that a ten-point increase in perceived risk (on a $0-100$ probability scale in which mean risk is 46.5 for theft and 43.6 for violence) is associated with a three percent reduction in the expected number of thefts and a five percent reduction in the expected number of violent acts. ${ }^{20}$ The corresponding effects for rewards are larger: A ten-point decrease in the probability of "being seen as cool" is associated with a six percent reduction in theft and a seven percent reduction in violence. For excitement, the effect is a six percent reduction (for theft). Our finding that perceived

${ }^{20}$ Note that our sample of 1,472 individuals committed 3,321 acts of violence and 3,307 acts of theft (per year). Therefore, increasing the probability of arrest by 0.1 would be expected to "save" 156 acts of violence and 109 acts of theft in a year. risk of punishment has a small but significant effect is consistent with rational choice (and social learning) models of individual behavior, the utilitarian assumptions underlying our criminal justice system, and therefore, the legitimacy of using some minimal level of the threat of punishment imposed by the state.

But given that the United States has one of the highest arrest and imprisonment rates among Western nations, increasing the perceived probability of arrest by 0.1 would likely involve draconian steps by the criminal justice system. This implies that policies for increasing the objective probability of punishment, by themselves, may be of limited value for reducing the crime rate substantially (Cullen et al. 2002). Indeed, the modest explained variance in our models of theft (seven percent) and violence (nine percent) suggests that other processes, such as socialization and embeddedness in institutions, may dwarf the effects of punishment and suggest more efficient policy interventions. ${ }^{21}$

Our results suggest equally promising avenues for intervention: school programs to Irteach peer groups that crime is not cool; institutional programs to increase opportunity costs to crime by enhancing human capital; and recreational programs to provide outlets for youth with strong preferences for risk and excitement (for promising leads, see Elliott, Hamburg, and Williams 1998). Furthermore, our finding that delinquents learn they can get away with crime (and each undetected offense further reduces their estimates of the risk of arrest) underscores the importance of early interventions, occurring before delinquent careers develop and risk estimates decline. Perhaps educational programs teaching youth that the actual long run risk of detection over a criminal career is actually high may be worth pursuing.

Given the modest effects of the perceived threat of punishment, it is troubling that "get tough on crime" policies, such as sentencing guidelines, "three strikes and you're out" laws, and mandatory minimum sentences have gained such traction at the outset of the 21 st century.

${ }^{21}$ We are using a pseudo- $\mathrm{R}^{2}$ based on the likelihood ratio test statistic: $\mathrm{R}^{2}=1-\left(\mathrm{L}_{\alpha} / \mathrm{L}_{\beta}\right)^{2 / n}$, where $\mathrm{L}_{\alpha}$ is the maximum of the likelihood function for an intercept-only null model and $\mathrm{L}_{\beta}$ is that for the hypothesized model (see Long 1997). 
This is particularly ironic given that Beccaria's ([1764] 1963) proposed system of justice based on utilitarian ideas emphasized curtailing the severity of punishments and using them only as a last resort.

Sociological analyses suggest that the rationale for punishment has less to do with deterrence and more to do with larger political processes endemic to U.S. capitalism, particularly in late modernity. For example, Garland (2001) compares the United States to England and despairs that, in late modernity, a culture of risk management (backed by economic rationality), centralized state power (which has shifted decision making away from criminal justice practitioners to politicians), and a shift from welfare (rehabilitation and prevention) to penal orientations has led to policies of severe punishment, increasing surveillance, and determinate sentencing. Garland's conclusions about late modernity rest on commonalities between contemporary United States and England. In contrast, Whitman (2003) holds constant late modernity by contrasting contemporary United States with France and Germany. Heconcludes Uthat the confluence of a strong state (in which bureaucrats are free to interpret-soften - the law to fit individual circumstances) (see Rosett and Cressey 1976) and memories of the brutal punishments doled out to the lower classes during the "reign of terror" led to mild punishments (mercy) for all offenders in France and Germany. This "leveling up" of treatment to approximate that of aristocrats is absent in the United States because of its weak state and because U.S. citizens lack a shared history of brutality. The result is a shift from the judicial to the legislative, whereby mechanical punishments are subject to political processes in which parties clamor to appear tough on crime.

Policies of getting tough on crime always resonate well in the U.S. political arena. However, such resonance is often based more on ideology than empirical research on punitive practices, such as evaluations of California's Three Strikes laws that show at best small general deterrent effects (e.g., Zimring, Hawkins, and Kamin 2001), and our findings of modest deterrent effects of perceived certainty of arrest. The finding of some deterrent effect, however modest, is not surprising, given the need for the appearance of legitimacy in the legal system to maintain the consent of the governed. What is surprising, however, is the persistence of increasingly harsh punitive crime policies in the United States in the face of this growing body of research.

Ross L. Matsueda is Professor of Sociology at the University of Washington and is a Visiting Scholar at the University of Wisconsin-Madison. His research interests center on the sociology of crime, law, and deviance, social psychology, and methods. His current projects include the Seattle Neighborhoods and Crime Project (with Robert Crutchfield, Avery Guest, and Kevin Drakulich), which is a study of neighborhood organization, codes of the street, and spatial dynamics of violence in Seattle neighborhoods; Life Course Trajectories of Drug Use and Crime (with Kreager, Huizinga, and Elena Erosheva); and sibling models of child behavior problems (with Lingxin Hao).

Deren A. Kreager is a Ph.D. candidate in the Department of Socioiogy at the University of Washington. His research interests include crime, the life course, deterrence, and social network analysis. His dissertation explores the links between peer networks and adolescent violence. His recent work includes "Strangers in the Halls: Isolation and Delinquency in School Networks" Social Forces 83(2004):351-90.

David Huizinga is Senior Research Associate in the Institute for Behavioral Science at the University of Colorado. He is principal investigator of the Denver Youth Survey, now in its 19th year, and has been coprincipal and principal investigator of the National Youth Survey, now in its 29th year. Both are longitudinal studies of problem and successful behaviors over the life course that focus on delinquency, violence, drug use, victimization, and mental health. He has also recently been the principal investigator of two comparative studies (with Karl Schumann) investigating the effect of the transition from school to work and the effect of juvenile justice processing on subsequent criminal behavior in Germany and the United States. 


\section{APPENDIX}

Table A1. Concepts and Measures

\begin{tabular}{|c|c|}
\hline Variables & Description \\
\hline \multicolumn{2}{|l|}{ Background and Contextual Variables } \\
\hline Female & Dummy variable for sex \\
\hline Age & Age of respondent in 1988 \\
\hline Black & Dummy variable for blacks \\
\hline Hispanic & Dummy variable for Hispanic origin \\
\hline No Siblings & Dummy variable for respondents without siblings \\
\hline Concentrated Disadvantage & $\begin{array}{l}\text { Sum of percent poverty, percent unemployed, percent female-headed } \\
\text { households by census block group }\end{array}$ \\
\hline Proportion Black & Percent black by census block group \\
\hline Residential Stability & $\begin{array}{l}\text { Sum of percent homeowners and percent in same household by census } \\
\text { block group }\end{array}$ \\
\hline Crime Rate 1984 & $\begin{array}{l}\text { Total number of crimes reported to police in } 1984 \text { per ten residents by } \\
\text { neighborhood }\end{array}$ \\
\hline High Impulsivity & $\begin{array}{l}\text { Parent strongly agrees with } 1988 \text { items (1) Can't sit still, restless, or } \\
\text { hyperactive, (2) Impulsive or acts without thinking, (3) Wants to have } \\
\text { things right away, (4) impatient }(\alpha=.72)\end{array}$ \\
\hline Biological Parents $_{t-1}$ & Dummy variable indicating living with both biological parents \\
\hline Parent(s) on Welfare ${ }_{t-1}$ & Dummy variable for welfare receipt reported by parent \\
\hline Family Income t-1 $_{1}$ & Family income reported by parent, in $\$ 1000$ 's \\
\hline Missing Parent Report $\mathrm{t}_{\mathrm{t}-1}$ & Dummy variable for missing on income or welfare (no parent interview) \\
\hline \multicolumn{2}{|l|}{ Explanatory Variables } \\
\hline Experienced Certainty $y_{t}$ & $\begin{array}{l}\text { Ratio of number of times questioned or arrested by police to self-reported } \\
\text { crimes, cumulative across waves, and categorized into three dummy } \\
\text { variables with non-offending the omitted category }\end{array}$ \\
\hline Unsanctioned Offenses $_{t}$ & $\begin{array}{l}\text { Three dummy variables indicating levels of self-report offending for } \\
\text { offenders who have not been questioned or arrested by the police }\end{array}$ \\
\hline Peer Theft $t_{t}$ & $\begin{array}{l}\text { Number of friends in the past year who have (1) stolen something worth } \\
\text { less than } \$ 5,(2) \text { stolen something between } \$ 5-\$ 100,(3) \text { stolen some- } \\
\text { thing worth more than } \$ 100(\alpha=.82)\end{array}$ \\
\hline Peer Violence $_{t}$ & $\begin{array}{l}\text { Number of friends in the past year who have (1) gotten into a fight with } \\
\text { schoolmates or friends, }(2) \text { hit someone with the idea of hurting them, } \\
\text { (3) attacked someone with a weapon or with the idea of seriously } \\
\text { hurting them }(\alpha=.84)\end{array}$ \\
\hline Police Contact $t_{-1}$ & Sum of self-reported counts: (1) arrested, or (2) questioned by police \\
\hline Risk Preference $_{t-1}$ & Do you agree with the statement, "I like to do daring things" \\
\hline Grades $_{\mathrm{t}-1}$ & Self-reported grade-point average \\
\hline Not in School t-1 $_{1}$ & Missing grades due to not being in school \\
\hline Employed $_{\mathrm{t}-1}$ & Dummy variable indicating self-reported employment during the past year \\
\hline Theft (Violence) Excitement $t-1$ & $\begin{array}{l}\text { Perceived probability of excitement for committing theft (violence) } \\
(0-10010 \text { point increments) weighted by how good or bad that would } \\
\text { be (5-point scale) }\end{array}$ \\
\hline Theft (Violence) Coolness ${ }_{t-1}$ & $\begin{array}{l}\text { Perceived probability of being seen as cool for committing theft (vio- } \\
\text { lence) weighted by how good or bad that would be }\end{array}$ \\
\hline $\begin{array}{l}\text { Theft (Violence) Perceived Risk } \\
\text { of Arrest } t_{-1}\end{array}$ & $\begin{array}{l}\text { Perceived probability of being picked up by the police for committing } \\
\text { theft (violence) weighted by how good or bad that would be }\end{array}$ \\
\hline Theft (Violence) Opportunities ${ }_{t}$ & $\begin{array}{l}\text { How often do you have a chance to commit theft (violence) and get away } \\
\text { with it? (Five-point scale) }\end{array}$ \\
\hline Prior Theft (Violence) $)_{\mathrm{t}-1}$ & Logged sum of prior theft and violence counts (see below) \\
\hline
\end{tabular}

Dependent Variables

Theft (Violence) Perceived Risk of Perceived probability of being picked up by police for theft (violence)

Arrest $_{\mathrm{t}-1}$

Violence $_{t}$

Sum of self-reported violence counts: (1) aggravated assault, (2) simple assault, (3) gang fights

Theft $_{t}$

Sum of self-reported theft counts: (1) stolen less than $\$ 5$, (2) stolen between $\$ 5$ and $\$ 100$, (3) stolen over $\$ 100$, (4) shoplifting, (5) purse snatching, (6) auto larceny, (7) fencing 


\section{REFERENCES}

Achen, Christopher H. 1992. "Social Psychology, Demographic Variables, and Linear Regression: Breaking the Iron Triangle in Voting Research." Political Behavior 14:195-211.

Akers, Ronald L. 1998. Social Learning and Social Structure. Boston, MA: Northeastern University. Andenaes, Johannes. 1975. "General Prevention Revisited: Research and Policy Implications." Journal of Criminal Law and Criminology 66:338-65.

Anderson, Elijah. 1999. Code of the Street: Decency, Violence and the Moral Life of the Inner City. New York: W. W. Norton.

Barron, David N. 1992. "The Analysis of Count Data: Overdispersion and Autocorrelation." Pp. 179-220 in Sociological Methodology, vol. 22, edited by P. V. Marsden. Cambridge, MA: Blackwell Publishers.

Beccaria, Cesare. [1764] 1963. On Crimes and Punishments. Indianapolis, IN: Bobbs-Merrill.

Becker, Gary S. 1968. "Crime and Punishment: An Economic Approach." Journal of Political Economy 76:169-217.

Bentham, Jeremy. [1789] 1948. An Introduction to the Principle of Morals and Legislations. Oxford, UK: Blackwell.

Delivered

Blackwell, Brenda Sims and Sarah Eschholz. 2002. "Sex Differences in Rational Choice: Traditional Tests and New Directions." Pp. 109-36 in Raiionat Choice and Criminal Behavior: Recent Research and Future Challenges, edited by A. R. Piquero and S. G. Tibbetts. New York: Routledge.

Carroll, J. S. 1978. "A Psychological Approach to Deterrence: The Evaluation of Crime Opportunities." Journal of Personality and Social Psychology 36:1512-20.

Chambliss, William J. 1967. "Types of Deviance and the Effectiveness of Legal Sanctions." Wisconsin Law Review Summer:703-19.

Clarke, Ronald V. and Derek B. Cornish. 1985. "Modeling Offenders' Decisions: A Framework for Research and Policy." Pp. 147-85 in Crime and Justice: An Annual Review of Research, Volume 6, edited by N. Morris and M. Tonry. Chicago, IL: University of Chicago Press.

Cloward, Richard A. and Lloyd E. Ohlin. 1960. Delinquency and Opportunity. New York: Free Press.

Cohen, Albert K. 1955. Delinquent Boys. New York: Free Press.

Cohen, Lawrence E. and Marcus Felson. 1979. "Social Change and Crime Rate Trends: A Routine Activity Approach." American Sociological Review 44:588-608.

Coleman, James S. 1990. Foundations of Social Theory. Cambridge, MA: Harvard.

Cook, Philip. 1980. "Research in Criminal
Deterrence: Laying the Groundwork for the Second Decade." Pp. 211-68 in Crime and Justice: An Annual Review of Research, vol. 2, edited by N. Morris and M. Tonry. Chicago, IL: University of Chicago Press.

Cragg, John G. 1971. "Some Statistical Models for Limited Dependent Variables with Application to the Demand for Durable Goods." Econometrica 39:829-44.

Cullen, Francis T., Travis C. Pratt, Sharon Levran Miceli, and Melissa M. Moon. 2002. "Dangerous Liaison? Rational Choice Theory as the Basis for Correctional Intervention." Pp. 279-97 in Rational Choice and Criminal Behavior, edited by A. R. Piquero and S. G. Tibbetts. New York: Routledge. Douglas, Mary. 1986. How Institutions Think. Syracuse, NY: Syracuse University Press.

Ehrlich, Isaac. 1973. "Participation in Illegitimate Activities: A Theoretical and Empirical Investigation." Journal of Political Economy 81:521-65.

Elliott, Delbert S., Beatrix Hamburg, and Kirk R. Williams, eds. 1998. Violence in American Schools. New York: Cambridge University Press.

Esbensen, Finn-Aage and David Huizinga. 1990. "Community Structure and Drug Use: From a Social Disorganization Perspective." Justice Quarterly 7:691-709 nit (cid 292294), matsued

Frazier, Charles E. and Thomas Meisenhelder. 1985. "Exploratory Notes on Criminality and Emotional Ambivalence." Qualitative Sociology 8:266-284.

Garland, David. 1990. Punishment and Modern Society. Chicago, IL: University of Chicago.

. 2001. The Culture of Control. Chicago, IL: University of Chicago.

Greene, William H. 2002. LIMDEP Version 8.0 Reference Guide. Plainview, NY: Econometric Software, Inc. . 2003. Econometric Analysis. Upper Saddle River, NJ: Prentice Hall.

Gottfredson, Michael R. and Travis Hirschi. 1990. A General Theory of Crime. Stanford, CA: Stanford University Press.

Hagan, John and Bill McCarthy. 1997. Mean Streets: Youth Crime and Homelessness. New York: Cambridge University Press.

Hagan, John, John Simpson, and A. R. Gillis. 1987. "Class in the Household: A Power-Control Theory of Gender and Delinquency." American Journal of Sociology 92:788-816.

Hausman, Jerry, Bronwyn Hall, and Zvi Griliches. 1984. "Econometric Models for Count Data with an Application to the Patents-R \& D Relationship." Econometrica 52:909-38.

Hechter, Michael and Satoshi Kanazawa. 1997. "Sociological Rational Choice Theory." Annual Review of Sociology 23:191-214.

Heimer, Carol A. 1988. "Social-Structure, 
Psychology, and the Estimation of Risk." Annual Review of Sociology 14:491-519.

Hirschi, Travis. 1969. Causes of Delinquency. Berkeley, CA: University of California Press.

Horney, Julie and Ineke H. Marshall. 1992. "Risk Perceptions Among Serious Offenders: The Role of Crime and Punishment." Criminology 30:575-94.

Horowitz, Ruth. 1983. Honor and the American Dream. New Brunswick, NJ: Rutgers University Press.

Hume, David. [1739] 2000. A Treatise of Human Nature, edited by David Fate Norton and Mary J. Norton. Oxford, UK: Oxford University Press.

Jacob, Herbert. 1979. "Rationality and Criminality." Social Science Quarterly 59:584-5.

Jacobs, Bruce A. 2000. Robbing Drug Dealers. New York: Aldine.

Jenkins, Patricia H. 1995. "School Delinquency and School Commitment." Sociology of Education 68(3):221-39.

Jensen, Gary. 1969. "Crime Doesn't Pay: Correlates of a Shared Misunderstanding." Social Problems 17:189-201.

Kahneman, Daniel and Amos Tversky. 1972. "Subjective Probability: A Judgment of Representativeness." Cognitive Psychology 3:430-54.

Kahneman, Daniel, peter P. Wakker, and Rakesh Sarin. 1997. "Back to Bentham? Explorations of Experienced Utility." The Quarterly Journal of Economics 112:375-405.

Katz, Jack. 1988. Seductions of Crime: Moral and Sensual Attractions in Doing Evil. New York: Basic Books, Inc.

Klepper, Steven and Daniel S. Nagin. 1989. "The Deterrent Effect of Perceived Certainty and Severity of Punishment Revisited." Criminology 27:721-46.

Langley, John, producer. [1988] 2005. Cops. Television series. Los Angeles, CA: Fox Broadcasting Company.

Levitt, Steven. 1997. "Using Electoral Cycles in Police Hiring to Estimate the Effect of Police on Crime." American Economic Review 87:270-90.

Lochner, Lance. 2005. "Individual Perceptions of the Criminal Justice System.” Working Paper No. 9474, National Bureau of Economic Research, Cambridge, MA.

Long, Scott. 1997. Regression Models for Categorical and Limited Dependent Variables. Thousand Oaks, CA: Sage.

Maddala, G. S. 1983. Limited-Dependent and Qualitative Variables in Econometrics. Cambridge, UK: Cambridge University Press.

Maestro, Marcello T. 1973. Cesare Beccaria and the Origins of Penal Reform. Philadelphia, PA: Temple University.

Marvell, Thomas and Carlisle Moody. 1994. "Prison
Population Growth and Crime Reduction." Journal of Quantitative Criminology 10:109-40.

Matsueda, Ross L. 1992. "Reflected Appraisals, Parental Labeling, and Delinquent Behavior: Specifying a Symbolic Interactionist Theory." American Journal of Sociology 97:1577-1611.

McCall, Nathan. 1994. Makes Me Wanna Holler. New York: Vintage.

McCarthy, Bill. 2002. "New Economics of Sociological Criminology." Annual Review of Sociology 28:417-42.

McCarthy, Bill and John Hagan. 2005. "Danger, Deterrence, and the Decision to Offend." Social Forces 83:1065-96.

McCullagh, P. and J. A. Nelder. 1997. Generalized Linear Models. $2 \mathrm{~d}$ ed. London, UK: Chapman \& Hall.

McFadden, Daniel L. and Kenneth E. Train. 1996. "Consumers' Evaluation of New Products: Learning from Self and Others." Journal of Political Economy 104:683-703.

Morrow, James D. 1994. Game Theory for Political Scientists. Princeton, NJ: Princeton University.

Nagin, Daniel S. 1978. "General Deterrence: A Review of the Empirical Evidence.” Pp. 95-139 in Deterrence and Incapacitation: Estimating the Effects of Criminal Sanction on Crime Rates, edited by A: Blumstein, J. Cohen, and D. Nagin. Wâshiningtôn, DE: National Academy Press. 1998. "Criminal Deterrence Research at the Outset of the Twenty-First Century." Crime and Justice: A Review of Research 23:1-42.

Nagin, Daniel S. and Raymond Paternoster. 1994. "Personal Capital and Social Control: The Deterrence Implications of Individual Differences in Criminal Offending." Criminology 32:581-606.

Nagin, Daniel S. and Greg Pogarsky. 2001. "Integrating Celerity, Impulsivity, and Extralegal Sanction Threats into a Model of General Deterrence: Theory and Evidence." Criminology 39:865-92.

Parker, Jerry and Harold G. Grasmick. 1979. "Linking Actual and Perceived Certainty of Punishment: An Exploratory Study of an Untested Proposition in Deterrence Theory." Criminology 17:365-79.

Pashukanis, Evgeny B. [1929] 1978. Law and Marxism: A General Theory, edited by Chris Arthur. London, UK: Ink Links.

Paternoster, Raymond. 1987. "The Deterrence Effect of the Perceived Certainty and Severity of Punishment: A Review of the Evidence and Issues.” Justice Quarterly 4:173-217.

Paternoster, Raymond, Shawn Bushway, Robert Brame, and Robert Apel. 2003. "The Effect of Teenage Employment on Delinquency and Problem Behaviors." Social Forces 82:297-335.

Piliavin, Irving, Rosemary Gartner, Craig Thornton, and Ross L. Matsueda. 1986. "Crime, Deterrence, 
and Rational Choice." American Sociological Review 51:101-19.

Pinderhughes, Howard. 1997. Race in the Hood: Conflict and Violence Among Urban Youth. Minneapolis: University of Minnesota.

Piquero, Alex R. and Greg Pogarsky. 2002. "Beyond Stafford and Warr's Reconceptualization of Deterrence: Personal and Vicarious Experiences, Impulsivity, and Offending Behavior." Journal of Research in Crime and Delinquency 39:153-86.

Ploeger, Matthew. 1997. "Youth Employment and Delinquency: Reconsidering a Problematic Relationship." Criminology 35:659-75.

Pogarsky, Greg and Alex R. Piquero. 2003. "Can Punishment Encourage Offending? Investigating the "Resetting" Effect." Journal of Research in Crime and Delinquency. 40(1):95-120.

Pogarsky, Greg, Alex R. Piquero, and Raymond Paternoster. 2004. "Modeling Change in Perceptions about Sanction Threats: The Neglected Linkage in Deterrence Theory." Journal of Quantitative Criminology 20:343-69.

Posner, Richard A. 1998. Economic Analysis of Law, 5th ed. Boston, MA: Aspen Law \& Business.

Raftery, Adrian E. 2001. "Statistics in Sociology, 1950-2000: A Selective Review." Sociological Methodology 31:1-46.

Rosett, Arthur, and Donald R. Cressey. 1976. Yussice Uni by consent. Phitadelphia, pA: Dippincott.00477.

Sampson, Robert J. and Jacqueline Cohen. 1988. "Deterrent Effects of Police on Crime: A Replication and Theoretical Extension." Law and Society Review 22:163-89.

Sampson, Robert J. and John H. Laub. 1993. Crime in the Making: Pathways and Turning Points Through Life. Cambridge, MA: Harvard University Press.

Short, James F., Jr. and Fred L. Strodtbeck. 1965. Group Process and Gang Delinquency. Chicago, IL: University of Chicago.

Staff, Jeremy and Christopher Uggen. 2003. "The Fruits of Good Work: Early Work Experiences and Adolescent Deviance." Journal of Research in Crime and Delinquency 40:263-90.

Stafford, Mark C. and Mark Warr. 1993. "A Reconceptualization of General and Specific Deterrence." Journal of Research in Crime and Delinquency 30:123-35.

Stewart, Eric A. 2003. "School Social Bonds, School Climate, and School Misbehavior: A Multilevel Analysis." Justice Quarterly 20(3):575-604.

Steinberg, Laurence, Suzanne Fegley, and Sanford M. Dornbusch. 1993. "Negative Impact of Part-Time
Work on Adolescent Adjustment: Evidence from a Longitudinal-Study." Developmental Psychology 29:171-80.

Sullivan, Mercer L. 1989. "Getting Paid”: Youth Crime and Work in the Inner City. Ithaca, NY: Cornell University Press.

Sunstein, Cass R. 1999. "Behavioral Law and Economics: A Progress Report." American Law and Economics Review 1:115-57.

Tallman, Irving and Louis N. Gray. 1990. "Choices, Decisions, and Problem-Solving." Annual Review of Sociology 16:405-33.

Tittle, Charles R. 1980. Sanctions and Social Deviance: The Question of Deterrence. New York: Praeger.

Tunnell, Kenneth D. 1992. Choosing Crime: The Criminal Calculus of Property Offenders. Chicago, IL: Nelson-Hall.

Tversky, Amos and Daniel Kahneman. 1974. "Judgment Under Uncertainty: Heuristics and Biases." Science 185:1124-31.

Weber, Max. [1921/1922] 1978. Economy and Society, edited by G. Roth and C. Wittich. Berkeley, CA: University of California Press.

Whitman, James Q. 2003. Harsh Justice. Oxford, UK: Oxford University.

Williams, Kirk R. and Richard Hawkins. 1986. "Perceptual Research on General Deterrence: A Critical Review." Law and Society Review 20.545-72.

Wilson, James Q. and Barbara Boland. 1978. "The Effect of the Police on Crime." Law and Society Review 12:367-90.

Wilson, James Q. and Richard J. Herrnstein. 1985. Crime and Human Nature: The Definitive Study of the Causes of Crime. New York: Simon and Schuster.

Winterfeldt, Detlof Von and Ward Edwards. 1986. Decision Analysis and Behavioral Research. Cambridge, UK: Cambridge University Press.

Wooldridge, Jeffrey. 2002. Econometric Analysis of Cross Section and Panel Data. Cambridge, MA: MIT Press.

Wright, John Paul, Francis T. Cullen, and Nicolas Williams. 1997. "Working While in School and Delinquent Involvement: Implications for Social Policy." Crime and Delinquency 43:203-21.

Zimring, Franklin E. and Gordon J. Hawkins. 1973. Deterrence. Chicago, IL: University of Chicago.

Zimring, Franklin E., Gordon J. Hawkins, and Sam Kamin. 2001. Punishment and Democracy. New York: Oxford University. 